\title{
Nitrogen and carbon uptake kinetics and the influence of irradiance for a red tide bloom off southern California
}

\author{
Raphael M. Kudela ${ }^{1, *}$, William P. Cochlan ${ }^{2}$ \\ ${ }^{1}$ Ocean Sciences Department, University of California, Santa Cruz, 1156 High Street, Santa Cruz, California 95064, USA \\ ${ }^{2}$ Romberg Tiburon Center for Environmental Studies, San Francisco State University, PO Box 855, 3150 Paradise Drive, \\ Tiburon, California 94920, USA
}

\begin{abstract}
The kinetics of nitrogen (nitrate, ammonium, urea) and carbon uptake by a red tide bloom consisting almost exclusively of the dinoflagellate Lingulodinium polyedrum (Stein) Dodge were determined with ${ }^{15} \mathrm{~N}$ - and ${ }^{13} \mathrm{C}$-tracer techniques, as a function of substrate concentration (for nitrogen) and irradiance (for both carbon and nitrogen). Samples were collected from Newport Beach, California, in late March 1995, during a massive red tide bloom which occurred off the California coast. At the collection site, surface concentrations of $L$. polyedrum reached $1.1 \times 10^{6}$ cells $l^{-1}$, with chlorophyll $a=$ $125 \mathrm{\mu g} \mathrm{l}^{-1}$. Maximal uptake rates of urea-N were approximately twice the maximal rates for either ammonium or nitrate during both the uptake versus substrate and uptake versus irradiance experiments, and the affinity for nitrate was much greater than previously demonstrated: half-saturation constant $\left(K_{s}\right)=0.47 \mu \mathrm{g}$-at $\mathrm{N}^{-1}$. Carbon and nitrogen uptake rates as a function of irradiance were well described by a 3 -parameter $\mathrm{P}$ versus $E$ relationship (photosynthesis vs irradiance) proposed by Platt \& Gallegos (1980), although dark-uptake of nitrogen compounds accounted for ca $50 \%$ of $V_{\max }$. These results demonstrate that $L$. polyedrum is capable of utilizing a broad range of both nitrogen concentrations and light fluences, and that urea could potentially provide a large percentage of the nitrogen demand at ambient urea concentrations and across the entire spectrum of light fluences. These data represent a more complete quantification of the $\mathrm{N}$ uptake dynamics of this bloom-forming species and contrast markedly compared to previous studies of L. polyedrum.
\end{abstract}

KEY WORDS: Lingulodinium polyedrum · Carbon · Nitrogen · Urea · Irradiance $\cdot$ Uptake kinetics

\section{INTRODUCTION}

During the late winter and early spring of 1995 , a massive red tide bloom composed primarily of the dinoflagellate Lingulodinium polyedrum (Stein) Dodge (basionym Gonyaulax polyedra) occurred off the coast of California. Although blooms of this organism are relatively common in these waters, this particular episode was unusual in both its spatial extent and its temporal occurrence. The 1995 bloom extended from the upper Baja peninsula in Mexico to Monterey Bay, California, and as far offshore as San Clemente Isiand. At

\footnotetext{
•E-mail:kudela@cats.ucsc.edu
}

Newport Beach, where our samples were collected, chlorophyll a (chl a) concentrations were $125 \mu \mathrm{g} \mathrm{l}^{-1}$ while cell counts were in excess of $1.1 \times 10^{6}$ cells l$^{-1}$; even greater values were reported at La Jolla, where chl a concentrations reached $519 \mu \mathrm{g} \mathrm{l}^{-1}$ and cell counts exceeded $2 \times 10^{6} \mathrm{I}^{-1}$ (Hayward et al. 1995). This represents the largest and most widespread red tide off California since 1902 (Torrey 1902). Typically, red tide blooms occur in southern California during the late spring and early summer, and the 1995 bloom was also the earliest known occurrence of a red tide for this region. Fortunately, $L$. polyedrum has rarely been reported to have direct toxic effects on other marine organisms, although a toxin similar to that which causes paralytic shellfish poisoning was first isolated 
from this species by Schradie \& Bliss (1962). Since that report, $L$. polyedrum has regularly been included in tables of algal toxicity and screened with variable results (see review by Lewis \& Hallett 1997). It appears, however, that marine fauna mortality associated with bloom concentrations of $L$. polyedrum is likely the result of deoxygenation and not direct toxicity.

Although Lingulodinium polyedrum has been extensively studied in both field (e.g. Holmes et al. 1967, Walsh et al. 1974, Eppley \& Harrison 1975, Macisaac 1978) and laboratory (e.g. Harrison 1976, Prézelin \& Sweeney 1979, Heaney \& Eppley 1981, Prézelin \& Matlick 1983, Balch 1985) conditions, relatively little is known about the nitrogenous nutrition of this species. These data represent the first study to simultaneously examine the utilization of nitrate, ammonium and urea as a function of concentration, and to determine the effects of irradiance on $N$ uptake. Previous studies have suggested that $L$. polyedrum must vertically migrate through the nutricline to obtain sufficient nitrogen to support observed growth rates (Maclsaac 1978, Heaney \& Eppley 1981). This was predicated on the elevated dark-uptake values and the abnormally high half-saturation $\left(K_{\mathrm{s}}\right)$ values for $\mathrm{NO}_{3}{ }^{-}$in this species. We demonstrate that at the time of our study, L. polyedrum was capable of meeting its nitrogen demands from regenerated nutrients exclusively, and that the $K_{\mathrm{s}}$ values for all $\mathrm{N}$ substrates are much lower than previously reported.

\section{MATERIALS AND METHODS}

Sampling. This opportunistic 2 d study was conducted with samples collected aboard the RV 'Marda' during a cruise off Newport Beach, California $\left(33^{\circ}\right.$ $34.58^{\prime} \mathrm{N}, 117^{\circ} 53.24^{\prime} \mathrm{W}$ ), on March 30, 1995, at approximately 10:30 h Pacific Daylight Time (PDT). Whole water was collected from the near surface using a clean plastic bucket, and stored in 2 acid-cleaned polyethylene carboys (rinsed $3 \times$ with sample water). The carboys were transported in dim light to the laboratory where they were placed in a walk-in culture room at low light $\left(25 \mu \mathrm{mol}\right.$ photons $\left.\mathrm{m}^{-2} \mathrm{~s}^{-1}\right)$, constant temperature $\left(14^{\circ} \mathrm{C}\right)$, and with a bubbling air source. Vertical

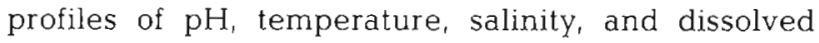
oxygen were conducted using a Seabird SBE19-03 CTD profiler equipped with an $\mathrm{O}_{2}$ sensor. Light was measured with a Biospherical Instruments profiling $4 \pi$ PAR meter with a matching deck unit. Discrete nutrient and pigment samples were collected using 51 Niskin bottles (equipped with silicon springs) deployed on a hydrowire. Nutrient and pigment samples were stored (frozen) on dry ice until analysis at the laboratory, and samples for the determination of species composition were collected and stored after preservation with acid
Lugol's solution. Additional samples for nutrients, pigments, and species composition were collected again immediately before the initiation of laboratory experiments.

Tracer uptake experiments. Water was dispensed into $280 \mathrm{ml}$ polycarbonate incubation bottles on March 31, 1995, ca $24 \mathrm{~h}$ after initial collection. Kinetic parameters of uptake for $\mathrm{NO}_{3}{ }^{-}, \mathrm{NH}_{4}{ }^{+}$, and $\mathrm{CO}\left(\mathrm{NH}_{2}\right)_{2}$ were measured by adding varying concentrations (10 substrate levels ranging from 0 to $36 \mu \mathrm{g}$-at ${ }^{15} \mathrm{~N}^{-1}$ (Cambridge Isotope Laboratories; all 99 atom $\%{ }^{15} \mathrm{~N}$ ) to duplicate sample bottles. Uptake versus irradiance parameters were determined by adding saturating concentrations (final concentration $=8.92 \mu \mathrm{g}$-at ${ }^{15} \mathrm{~N} \mathrm{I}^{-1}$ ) of the isotopes to duplicate sample bottles (except urea, for which no replicates were conducted). The ${ }^{15} \mathrm{NH}_{4}{ }^{+}$-labeled bottles were also inoculated (final concentration $=178.6 \mu \mathrm{g}$-at ${ }^{13} \mathrm{Cl}^{-1}$ ) with $\mathrm{NaH}^{13} \mathrm{CO}_{3}$ (Cambridge Isotope Laboratories; 99.9 atom $\%{ }^{13} \mathrm{C}$ ) for determination of carbon uptake rates.

The uptake kinetics experiments were conducted from 11:15 to $12: 30 \mathrm{~h}$ PDT, while the photosynthesis versus irradiance ( $\mathrm{P}$ vs $\mathrm{E}$ ) and $\mathrm{N}$ uptake velocity versus irradiance ( $V$ vs $E$ ) experiments were conducted from 14:30 to 15:35 h PDT. All incubations were conducted in clear Plexiglas ${ }^{\otimes}$ incubators on the roof of the Allen Hancock building at the University of Southern California (ambient sunlight, ca $2300 \mu \mathrm{mol}$ photons $\mathrm{m}^{-2} \mathrm{~s}^{-1}$ ). Ambient water temperature was maintained at $14 \pm 1^{\circ} \mathrm{C}$. The kinetics experiments were conducted at ca $50 \%$ of the average incident irradiance $\left(E_{0} ; \mu\right.$ mol photons $\mathrm{m}^{-2} \mathrm{~s}^{-1}$ ) while the $P$ versus $E$ and $V$ versus $E$ sample bottles were placed in clear Plexiglas ${ }^{\circledR}$ tubes wrapped with neutral-density film (Courtaulds Performance Films) to simulate the following light levels: $75,43,26$, $18,15,11.5,8.5,5,3,1$, and $0.27 \% E_{0}$. The $100 \%$ (unscreened) and $0 \%$ (wrapped in aluminum foil) bottles were not placed in Plexiglas ${ }^{\circledast}$ tubes, but were in the same incubator as the tubes.

All incubations were terminated by filtration (pressure differential <150 $\mathrm{mm} \mathrm{Hg}$ ) onto pre-combusted $\left(450^{\circ} \mathrm{C}, 4 \mathrm{~h}\right)$ Whatman GF/F filters, and the filters were immediately placed in a drying oven $\left(<60^{\circ} \mathrm{C},>24 \mathrm{~h}\right)$. The filters labeled with ${ }^{13} \mathrm{C}$ were acidified with 3 drops of $\mathrm{H}_{2} \mathrm{SO}_{3}$. Time-zero samples were taken to correct for cellular adsorption of the isotopes, and additional samples were taken to ensure that the addition of $\mathrm{H}_{2} \mathrm{SO}_{3}$ did not affect the ${ }^{15} \mathrm{~N}$ analysis. No dark bottle correction was made (e.g. dark bottles were not subtracted from light bottles) in the calculation of uptake rates (e.g. Li et al. 1993). Samples were prepared and analyzed for POC, PN and isotopic enrichment using a Europa Tracermass mass spectrometer.

Absolute uptake rates were calculated for both nitrogen and carbon using Eq. (3) in Dugdale \& Wilkerson (1986). For calculation of the carbon uptake rates, the 
ambient $\mathrm{TCO}_{2}$ concentration was assumed to be $2000 \mu \mathrm{g}$-at $\mathrm{C}$ (Slawyk 1979). This value is well within the error estimate of the $\mathrm{TCO}_{2}$ value estimated from $\mathrm{pH}$, salinity, and assumed total alkalinity (2008 $\mu \mathrm{g}$-at C) using the calculations of Lewis \& Wallace (1997). Uptake rates for ammonium and urea were not corrected for isotope dilution (Glibert et al. 1982), and therefore should be considered conservative estimates of uptake to the extent that isotope regeneration may have occurred at the relatively high ambient pre-inoculation nutrient concentrations during the short experimental periods utilized.

Analytical methods. Determinations of $\mathrm{NO}_{3}{ }^{-}+\mathrm{NO}_{2}{ }^{-}$ (hereafter referred to as $\mathrm{NO}_{3}{ }^{-}$) and $\mathrm{Si}(\mathrm{OH})_{4}{ }^{4-}$ were carried out using a Technicon AutoAnalyzer II following the procedures outlined in Wood et al. (1967) and Armstrong et al. (1967), respectively. Ammonium samples, collected directly into the polypropylene reaction containers and stored refrigerated after addition of the phenolic reagent, were manually analyzed (within $48 \mathrm{~h}$ ) using a spectrophotometer equipped with a $10 \mathrm{~cm}$ cell according to Sólorzano (1969). Urea samples (stored frozen) were also manually analyzed according to Price \& Harrison (1987) and modified to account for a longer $(30 \mathrm{~min})$ and lower $\left(80\right.$ to $\left.85^{\circ} \mathrm{C}\right)$ digestion temperature. Pigment samples (chls $a, b, c$, carotenoids and phaeopigments) were collected on combusted Whatman GF/F filters and stored frozen prior to extraction in $90 \%$ acetone for $24 \mathrm{~h}$ at $-20^{\circ} \mathrm{C}$. Analysis for pigments was conducted using a 1 or $10 \mathrm{~cm}$ cell following the spectrophotometric method described by Parsons et al. (1984) using the extinction coefficients provided therein. All nutrient and pigment samples were collected in duplicate; reported values are means of the replicates. Phytoplankton species samples were preserved in acid Lugol's solution (Parsons et al. 1984) and stored in the dark until enumeration following Utermöhl procedures (Utermöhl 1958).

Curve parameters. All curve fitting was completed using a computerized, iterative non-linear least-squares technique (Deltagraph, Deltapoint Inc.) which utilizes the Levenberg-Marquardt algorithm (Press et al. 1992) The nitrogen kinetics data were fitted to the MichaelisMenten formulation, after removing 1 extraneous point (see below):

$$
V=\frac{V_{\max } \times S}{K_{\mathrm{s}}+S}
$$

where $V$ is the specific uptake rate (pg-at $S$ cell $^{-1} \mathrm{~h}^{-1}$ ), $V_{\max }$ is the maximal specific uptake rate, $S$ is the substrate concentration ( $\mu \mathrm{g}$-at $S \mathrm{l}^{-1}$ ), and $K_{\mathrm{s}}$ is the half-saturation constant for the substrate ( $\mu \mathrm{g}$-at $S \mathrm{l}^{-1}$ ). Uptake versus irradiance data were fitted to the 3-parameter P versus E model proposed by Platt \& Gallegos $\left(1980_{i}\right.$ hereafter referred to as the Platt model) for both car- bon and nitrogen substrates. The original equation was modified to account for dark uptake by the inclusion of a positive $y$-intercept (as described by Cochlan et al. 1991 b):

$$
V=V_{s}\left(1-e^{\frac{-\alpha \times E}{V_{s}}}\right)\left(e^{\frac{-\beta \times E}{V_{s}}}\right)+V_{D}
$$

where $V_{\mathrm{s}}$ is the maximal uptake rate in the absence of photo-inhibition, $\alpha$ and $\beta$ are the respective light-limited and light-inhibited slopes of the uptake versus irradiance curve defined by the equation with units of (pg-at $\mathrm{S}$ cell ${ }^{-1} \mathrm{~h}^{-1}$ ) ( $\mu \mathrm{mol}$ photons $\left.\mathrm{m}^{-2} \mathrm{~s}^{-1}\right)^{-1}$, and E represents irradiance between 400 and $700 \mathrm{~nm}$ ( $\mu \mathrm{mol}$ photons $\mathrm{m}^{-2} \mathrm{~s}^{-1}$ ). For convenience we have not standardized the units for $\alpha$ and $\beta$ (i.e. converted to either $h^{-1}$ or $\mathrm{s}^{-1}$ ), but have left the units in the same form as was used for the $V$ and $E$ values. The $V_{D}$ term represents the positive intercept in the presence of dark-uptake, and is excluded from the carbon curves. Note that $V_{\max }$ and $V_{\mathrm{s}}$ are functionally equivalent if no photo-inhibition occurs, where $V_{\max }$ represents the maximal uptake rate observed, and $V_{\mathrm{s}}$ represents the maximal uptake rate in the absence of inhibition. The conventional index of light adaptation $\left(E_{\mathrm{k}}\right)$ is determined as the initial slope of the $V$ versus $E$ curve $\left(V_{\text {max }} / \alpha\right)$, and has units of $\mu \mathrm{mol}$ photons $\mathrm{m}^{-2} \mathrm{~s}^{-1}$. For clarity, we have utilized nitrogen symbols; the same equation can be parameterized for carbon by substituting the symbol $P^{\mathrm{B}}$ (biomass-specific carbon uptake) for $V$ (biomass-specific nitrogen uptake). Curve fits were completed using all available points; for ease of interpretation, the graphical representations provide the mean and error bars $( \pm 1 \mathrm{SD})$ for points where replicates were conducted.

As demonstrated by Frenette et al. (1993), intercomparison of various curve-fitting methods may lead to markedly different fitted parameters. All of these data demonstrated some degree of photo-inhibition, which is not accounted for by the Michaelis-Menten formulation. Furthermore, the fitted parameters $\left(V_{\max }, E_{\mathrm{k}}, \alpha\right)$ were similar using either the Platt model or the Michaelis-Menten hyperbola (modified to allow for dark-uptake) when the photo-inhibited samples were removed from the analyses (data not shown). Therefore, although most of the (few) previous studies of nitrogen uptake versus irradiance have used the Michaelis-Menten formulation, we present these data using the Platt model (except where noted). All curve fits (uptake vs irradiance, and uptake kinetics) are normalized to cell number. Rates are given in units of pgat $S$ cell $^{-1} \mathrm{~h}^{-1}$ which is calculated by dividing the absolute uptake rate $\left(\rho\right.$; pg-at $S \mathrm{~h}^{-1} \mathrm{l}^{-1}$ where $S$ is carbon or nitrogen) by the cell abundance (cell $\mathrm{l}^{-1}$ ). This rate is proportional to the biomass or $\mathrm{PN}$-specific rate $\left(V ; \mathrm{h}^{-1}\right)$. Statistical analyses for goodness-of-fit were 
determined using the variance approximation techniques described by Zimmerman et al. (1987).

\section{RESULTS}

\section{General hydrographic characteristics}

In the spring of 1995, a massive algal bloom composed of the dinoflagellate Lingulodinium polyedrum occurred off the west coast of North America, extending from the northern Baja peninsula to Monterey Bay, California. In Newport Beach, California, surface con-

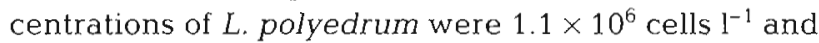
chl a concentrations were in excess of $125 \mathrm{mg} \mathrm{m}^{-3}$. Biomass maxima (as determined from photosynthetic pigments) were found at both the surface and subsurface $(6 \mathrm{~m})$. The deepest collection depth for this study $(10 \mathrm{~m})$ exhibited chl a concentrations in excess of $60 \mathrm{mg} \mathrm{m}^{-3}$, suggesting that the total biomass was substantially higher than the $835 \mathrm{mg} \mathrm{m}^{-2}$ calculated from trapezoidal integration of the upper $10 \mathrm{~m}$. The predominant pigment was chl $a$, although secondary pigments (primarily carotenoids) accounted for ca $40 \%$ of the total at all depths (Fig. 1). Phaeopigments were negligible at all depths, indicating that at the time of collection, the bloom was composed of active cells rather than degradation products. The diffuse attenuation coefficient $\left(K_{\mathrm{PAR}}\right)$ for these waters was $1.075 \mathrm{~m}^{-1}$. Floristic analyses of the samples indicated that $L$. polyedrum accounted for ca $97 \%$ of the autotrophic biovolume; co-occurrence of high concentrations of the heterotrophic dinoflagel- late Noctiluca scintillans resulted in ca 42 and $56 \%$ of the total biovolume being attributed to $L$. polyedrum and $N$. scintillans, respectively, The $N$. scintillans population was not accounted for in the present analysis due to previous results indicating this species to be an apochlorotic, obligate phagotrophic dinoflagellate (Buskey 1995). During the approximately 24 h that the samples were maintained in our culture facility, cell numbers of $L$. polyedrum approximately doubled while chl a declined from 125 to $61 \mu \mathrm{g} \mathrm{l}^{-1}$. No changes in the phaeopigment or accessory pigment to chl a ratios were detected, suggesting a physiologically mediated decrease in chlorophyll per cell.

Although previous dinoflagellate blooms of the California coast have often been associated with upwelling events (e.g. Dugdale 1979), the first 4 mo of 1995 for the southern California coast were characterized by positive sea surface temperature anomalies and negative upwelling index anomalies when compared to the long-term harmonic mean, and were accompanied by unusually heavy rainfall with comparably heavy coastal runoff throughout California (Hayward et al. 1995). Previous red tide blooms for this area have been reported from May to September (Hayward et al. 1995), which also makes this bloom the earliest known occurrence for this location. Vertical profiles indicated a relatively warm $\left(15.0^{\circ} \mathrm{C}\right)$ and fresh (32.95 PSS) strongly stratified upper water column with cooler $\left(12.9^{\circ} \mathrm{C}, 20 \mathrm{~m}\right)$, more saline $(33.45 \mathrm{PSS}, 20 \mathrm{~m})$ waters below the pycnocline located at approximately $12 \mathrm{~m}$ depth. Dissolved oxygen concentrations were supersaturated throughout the mixed layer.

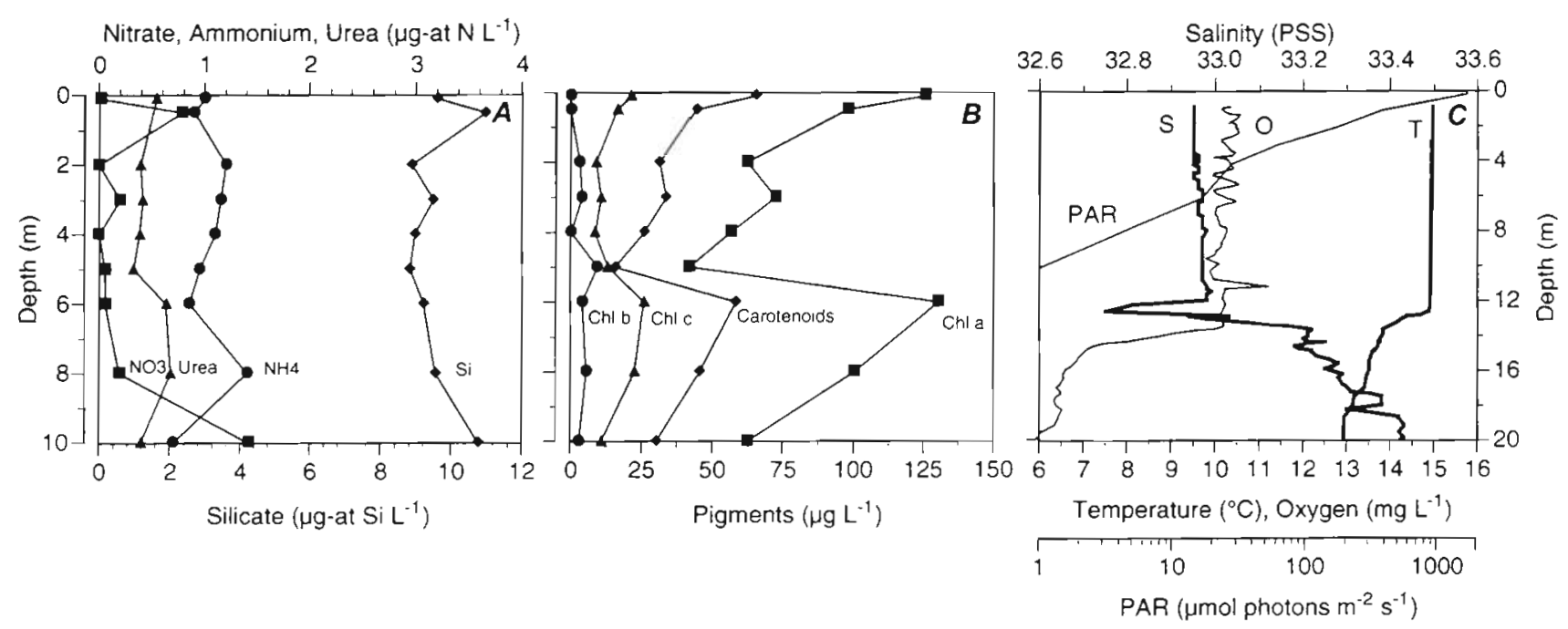

Fig. 1. Ambient conditions for the water column of Newport Beach, California, during sampling (March 30, 1995). (A) Depth pro-

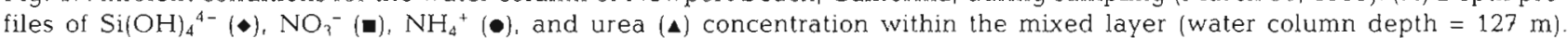
(B) Depth profile of plant pigment concentration ( $\mathbf{a}$ : chl $a_{i} \bullet$ : chl $b_{i} \Delta$ : chl $c_{i}$ and $\bullet$ carotenoids) within the mixed layer. (C) Temperature $\left({ }^{\circ} \mathrm{C}\right)$, salinity (PSS) oxygen $\left(\mathrm{mg} \mathrm{l}^{-1}\right)$ and photosynthetically available radiation (PAR; $\mu \mathrm{mol}$ photons $\mathrm{m}^{-2} \mathrm{~s}^{-1}$ ) at the study site. Note the change in depth ( $y$-axis) scale from 10 to $20 \mathrm{~m}$ in (C) 
Nutrient concentrations at the study site were typical of a red tide bloom (Eppley \& Harrison 1975), with elevated $\mathrm{Si}(\mathrm{OH})_{4}^{4-}$ concentrations and depleted $\mathrm{N}$ levels overlying a shallow thermocline and a deeper supply of $\mathrm{NO}_{3}{ }^{-}$. The anomalous near-surface peak at $0.5 \mathrm{~m}$ in $\mathrm{NO}_{3}{ }^{-}$and $\mathrm{Si}(\mathrm{OH})_{4}{ }^{4-}$ could be caused by freshwater runoff (Hayward et al. 1995; but note the lack of a corresponding salinity signal) aeolian deposition, or a mislabeled nutrient sample. Ammonium concentrations were elevated ( $\mathrm{ca} 1 \mu \mathrm{g}$-at $\mathrm{N} \mathrm{I}^{-1}$ ) throughout the water column, with a maximum occurring at $8 \mathrm{~m}$ depth, below the subsurface chl a maximum $(6 \mathrm{~m})$. Approaching the thermocline, $\mathrm{NO}_{3}{ }^{-}$concentrations increased while $\mathrm{NO}_{4}{ }^{+}$concentrations decreased. Measured urea concentrations (ca $0.5 \mu \mathrm{g}$-at $\mathrm{N}^{-1}$ ) were considerably lower than the $\mathrm{NO}_{4}{ }^{+}$concentrations; urea exhibited a similar profile to $\mathrm{NO}_{4}{ }^{+}$, with a subsurface maximum at ca 6 to $8 \mathrm{~m}$ (Fig. 1).

\section{Nitrogen kinetics}

The estimated kinetic parameters for the uptake of nitrate and urea are presented in Table 1 , and plotted in Fig. 2. It was not possible to determine the kinetics of ammonium using the iterative fitting procedure, due to elevated ambient concentrations present in the collected water $\left(0.75 \mu \mathrm{g}\right.$-at $\left.\mathrm{N} \mathrm{l}^{-1}\right)$. Fitting the data after linearizing with the Hanes-Woolf transformation (Dowd \& Riggs 1965) provided values of $0.586 \mu \mathrm{g}$-at $\mathrm{N} \mathrm{I}^{-1}$ and $1.01 \mathrm{pg}$-at cell ${ }^{-1} \mathrm{~h}^{-1}$ for the $K_{\mathrm{s}}$ and $V_{\max }$ respectively (Fig. 2). However, these values rely on the assumed linearity of the data and should only be considered as approximations. At the highest nutrient inoculation (36 $\mathrm{\mu g}$-at $\mathrm{NO}_{3}^{-} \mathrm{l}^{-1}$ ), $\mathrm{NO}_{3}^{-}$uptake was depressed $\left(0.231 \pm 0.063 \mathrm{pg}\right.$-at $\left.\mathrm{N}_{\text {cell }}{ }^{-1} \mathrm{~h}^{-1}\right)$ to less than

Table 1. Calculated kinetics parameters for uptake of $\mathrm{NO}_{3}^{-}$, urea, and $\mathrm{NH}_{4}{ }^{+}$Values for $\mathrm{NO}_{3}{ }^{-}$and urea were fitted using the Michaelis-Menten formulation; $\mathrm{NH}_{4}{ }^{+}$values were derived from linearization (Hanes-Woolf) of the available data, and are presented for comparison only. The $r^{2}$ column provides the coefficient of determination and the sample size ( $\mathrm{n}$ ). Units for $\alpha_{N}$ are (pg-at $N$ cell ${ }^{-1} h^{-1}$ ) ( $\mu g$-at $\left.\mathrm{N}^{-1}\right)^{-1}$. Cell abundance

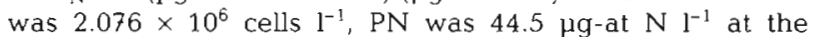
beginning of the experiment

\begin{tabular}{|lcccc|}
\hline & $\begin{array}{c}V_{\text {max }} \\
\left.\text { pg-at } \mathrm{N} \mathrm{cell}^{-1} \mathrm{~h}^{-1}\right)\end{array}$ & $\begin{array}{c}K_{5} \\
\left(\mu \text {-dt N l} ~^{-1}\right)\end{array}$ & $\alpha_{\mathrm{N}}$ & $\mathrm{r}^{2}$ \\
\hline $\mathrm{NO}_{3}{ }^{-}$ & 0.480 & 0.467 & 1.03 & 0.563 \\
$(\mathrm{SD})$ & $(0.034)$ & $(0.180)$ & $(0.051)$ & $(18)$ \\
Urea & 1.321 & 0.989 & 1.34 & 0.729 \\
$(\mathrm{SD})$ & $(0.119)$ & $(0.316)$ & $(0.111)$ & $(16)$ \\
$\mathrm{NH}_{4}{ }^{+}$ & 1.01 & 0.586 & 1.72 & 0.922 \\
$(\mathrm{SD})$ & $(0.069)$ & $(0.627)$ & $(0.397)$ & $(20)$ \\
\hline
\end{tabular}

half of our reported $V_{\max }$. We are not aware of any inhibitory or toxic effects in Lingulodinium polyedrum at these relatively low $\mathrm{NO}_{3}{ }^{-}$concentrations. It is unclear what the mechanism for this suppression was,
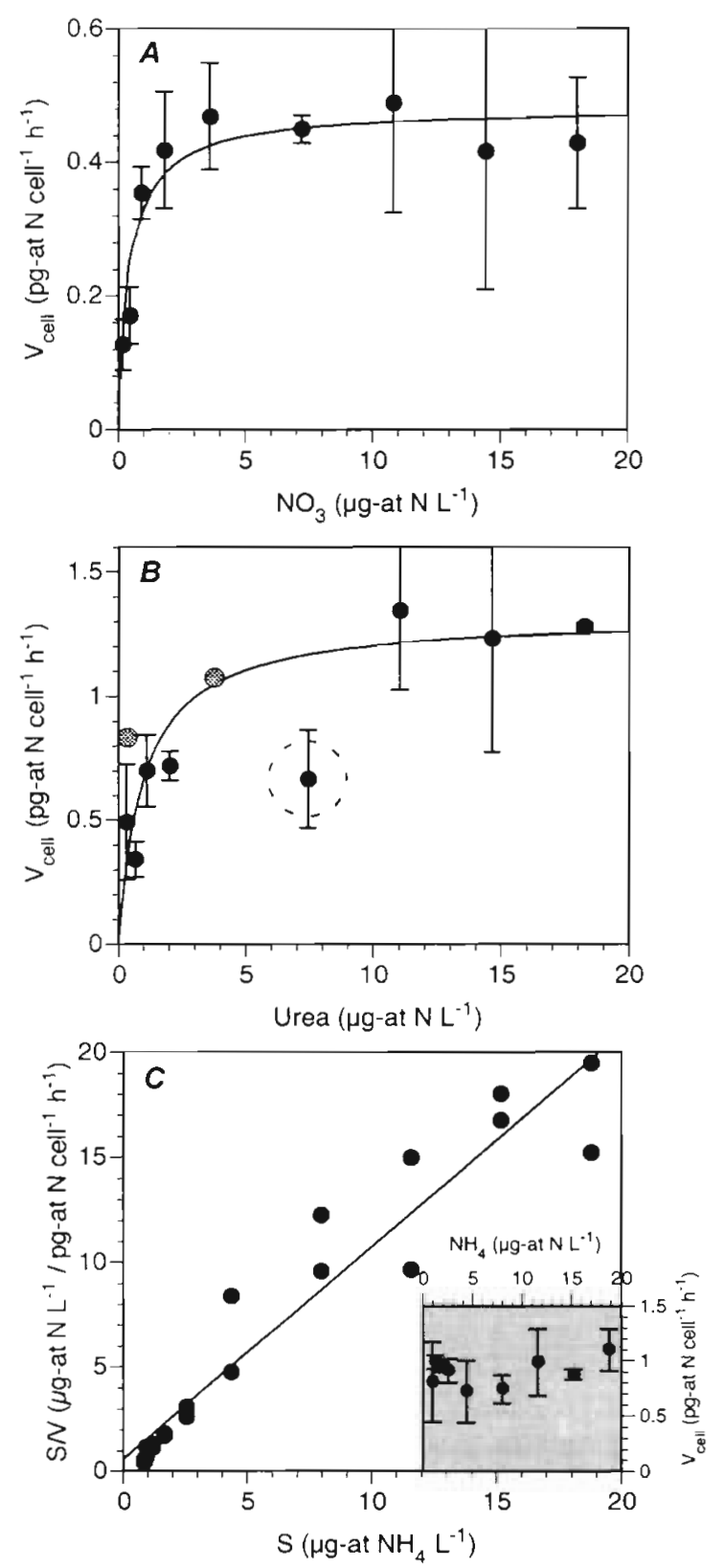

Fig. 2. Nitrogen uptake as a function of substrate concentration (A: $\mathrm{NO}_{3}{ }^{-}$; $\mathrm{B}$ : urea; $\mathrm{C}: \mathrm{NH}_{4}{ }^{+}$) for a natural assemblage of Lingulodinium polyedrum off Newport Beach, California. The curved plots are fitted directly to the Michaelis-Menten formulation. Error bars indicate \pm 1 SD of duplicate samples. Data in dashed circle were not included in the curve fit or in the estimation of kinetic parameters. non-replicate data. Note that for $\mathrm{NH}_{4}{ }^{+}$(C), a Hanes-Woolf linearization of the data is plotted, with the non-linearized data presented as an inset graph 
and these points were not used in our analyses. A comparison of maximal uptake rates ( $V_{\text {max }}$, pg-at $\mathrm{N}$ cell ${ }^{-1}$ $\mathrm{h}^{-1}$ ) indicated that uptake of urea was greatest, followed by uptake of $\mathrm{NH}_{4}{ }^{+}$and $\mathrm{NO}_{3}{ }^{-}$, with values of 1.32 , 1.01 and $0.480 \mathrm{pg}$-at $\mathrm{N}_{\text {cell }}{ }^{-1} \mathrm{~h}^{-1}$, respectively. The $K_{\mathrm{s}}$ for urea was also greater than that for both $\mathrm{NH}_{4}{ }^{+}$and $\mathrm{NO}_{3}{ }^{-}$, indicating that $L$, polyedrum could utilize lower concentrations of $\mathrm{NH}_{4}{ }^{+}$and $\mathrm{NO}_{3}{ }^{-}$compared to urea. Because of the effects of $V_{\max }$ on $K_{\mathrm{s}}$, these values are not necessarily a reliable indicator of preference at low nutrient concentrations (Healey 1980). The $\alpha$ parameter, referred to here as $\alpha_{\mathrm{N}}\left(\alpha_{\mathrm{N}}=V_{\max } / K_{\mathrm{si}}\right.$ [pg-at S cell ${ }^{-1}$ $\mathrm{h}^{-1} \mathrm{~J}\left[\mu \mathrm{g} \text {-at } S \mathrm{l}^{-1}\right]^{-1}$ ) to differentiate from the $\mathrm{P}$ versus $\mathrm{E}$ symbol, provides a more robust indicator for substrate affinity when substrate concentrations are low $\left(<K_{\mathrm{s}}\right)$, and substrate or inter-species competition is likely to occur (Healey 1980, Harrison et al, 1989, Cochlan \& Harrison 1991). The $\alpha_{\mathrm{N}}$ parameters $\left(\mathrm{NO}_{3}{ }^{-}, \mathrm{NH}_{4}{ }^{+}\right.$, urea) were within a factor of 2 .

\section{Uptake versus irradiance}

The estimated parameters for the uptake versus irradiance data are summarized in Table 2 for all substrates examined $\left(\mathrm{NO}_{3}{ }^{-}, \mathrm{NH}_{4}{ }^{+}\right.$, urea and carbon) and plotted in Fig. 3. Lower maximal uptake rates ( $V_{\max }$ ) were obtained for the nitrogen substrates in the uptake versus irradiance experiments compared to the kinetics experiments (using $V_{\max }$ values from MichaelisMenten curve fits for both data sets). There are several possibilities for this discrepancy, including the use of what we later determined to be less than saturating isotope enrichments (based on the kinetics experiments) or diurnal periodicity (e.g. MacIsaac 1978 , Miyazaki et al. 1987, Pettersson \& SahIsten 1990, Cochlan et al. 1991a, Glibert \& Garside 1992).
Although it was possible to fit the Platt model to all of these data, the $\mathrm{N}$ uptake data are not strictly lightdependent. Dark-uptake rates account for a significant proportion of the total uptake in these experiments, ranging from 37 to $52 \%$ of $V_{\max }$. In contrast, dark carbon uptake was ca $1.1 \%$ of $V_{\max }$ for carbon. Both carbon and $\mathrm{NO}_{3}{ }^{-}$uptake versus irradiance data exhibited low $E_{\mathrm{k}}$ values and correspondingly high values for the initial slope of the uptake versus irradiance curves $(\alpha)$. The $\alpha$ value for carbon (after converting to chl-specific uptake rates) is proportional to $98 \%$ of the theoretical maximal value proposed by Platt \& Jassby (1976) for coastal marine phytoplankton. All of the $N$ substrates exhibited similar affinities for uptake at low light levels, with $\alpha$ values ranging from 2.04 to $2.41 \times 10^{-3}$ (pg-at $\mathrm{N}$ cell $\left.^{-1} \mathrm{~h}^{-1}\right)\left(\mu \mathrm{mol} \text { photons } \mathrm{m}^{-2} \mathrm{~s}^{-1}\right)^{-1}$. Although the nitrogen substrate curves demonstrated pronounced uptake in the dark, the $E_{k}$ value for carbon was 2 to 10 times lower than for the $\mathrm{N}$ substrates $(25.8 \mu \mathrm{mol}$ photons $\mathrm{m}^{-2} \mathrm{~s}^{-1}$ vs 64.1 to $253 \mu \mathrm{mol}$ photons $\mathrm{m}^{-2} \mathrm{~s}^{-1}$ for carbon and nitrogen, respectively). These values, which represent the light intensity at the inflection point between light-limited and light-saturated uptake, translate into ca $1.2 \%$ of the average incident surface irradiance during the mid-afternoon incubations for carbon, and between 3 and $12 \%$ for nitrogen.

\section{DISCUSSION}

Lingulodinium polyedrum has been an oft-studied organism due to its frequent presence in red tide blooms off the southern California and Baja California coasts (review by Lewis \& Hallett 1997), including examination of both nutrient (e.g. Eppley \& Harrison 1975, Harrison 1976, MacIsaac 1978, Balch 1985) and light (e.g. Prézelin \& Sweeney 1979, Heaney \& Eppley

Table 2. Calculated uptake versus irradiance parameters for $\mathrm{NO}_{3}{ }^{-}, \mathrm{NH}_{4}{ }^{+}$, urea and carbon. All data were fitted to the Platt \& Gallegos (1980) model modified for dark uptake, and error analyses were determined using the methods described by Zimmerman et al. (1987). $S$ : various substrates being fitted; the Optimal \% $E_{0}$ column represents $E_{\mathrm{k}}$ as a percentage of near-surface irradiance $\left(E_{0}\right)$. The $\mathrm{r}^{2}$ column provides the coefficient of determination and the sample size $(n)$. Units for $\alpha$ and $\beta$ were omitted to conserve space the units are (pg-at $S$ cell $\left.{ }^{-1} \mathrm{~h}^{-1}\right) /\left(\mu \mathrm{mol}\right.$ photons $\left.\mathrm{m}^{-2} \mathrm{~s}^{-1}\right)$ for both

\begin{tabular}{|c|c|c|c|c|c|c|c|}
\hline & $\begin{array}{c}V_{\max } \\
\left(p g-a t S \text { cell }^{-1} \mathrm{~h}^{-1}\right)\end{array}$ & $\begin{array}{c}V_{\text {dark }} \\
\left(\text { pg-at } S \text { cell-1 } \mathrm{h}^{-1}\right)\end{array}$ & $\begin{array}{c}E_{k} \\
\left(\text { hmol photons } \mathrm{m}^{-2} \mathrm{~s}^{-1}\right)\end{array}$ & $\alpha$ & $\beta$ & $\begin{array}{l}\text { Optimal } \\
\% E_{\mathrm{o}}\end{array}$ & $\begin{array}{l}\mathrm{r}^{2} \\
(\mathrm{n})\end{array}$ \\
\hline $\begin{array}{l}\mathrm{NO}_{3}^{-} \\
(\mathrm{SD})\end{array}$ & $\begin{array}{c}0.321 \\
(0.026)\end{array}$ & $\begin{array}{c}0.166 \\
(0.002)\end{array}$ & 64.1 & $\begin{array}{l}2.41 \mathrm{E}^{-3} \\
\left(1.04 \mathrm{E}^{-3}\right)\end{array}$ & $\begin{array}{c}2.05 \mathrm{E}^{-5} \\
\left(2.86 \mathrm{E}^{-5}\right)\end{array}$ & 3.0 & $\begin{array}{c}0.769 \\
(26)\end{array}$ \\
\hline $\begin{array}{l}\mathrm{NH}_{4}{ }^{+} \\
(\mathrm{SD})\end{array}$ & $\begin{array}{c}0.488 \\
(0.126)\end{array}$ & $\begin{array}{c}0.182 \\
(0.018)\end{array}$ & 149 & $\begin{array}{c}2.05 \mathrm{E}^{-3} \\
\left(9.48 \mathrm{E}^{-4}\right)\end{array}$ & $\begin{array}{c}7.41 E^{-5} \\
\left(2.14 E^{-5}\right)\end{array}$ & 7.0 & $\begin{array}{c}0.801 \\
(23)\end{array}$ \\
\hline $\begin{array}{l}\text { Urea } \\
\text { (SD) }\end{array}$ & $\begin{array}{c}0.898 \\
(0.019)\end{array}$ & $\begin{array}{l}0.381 \\
\text { (ND) }\end{array}$ & 253 & $\begin{array}{c}2.04 E^{-3} \\
\left(6.67 E^{-5}\right)\end{array}$ & $\begin{array}{c}1.81 E^{-4} \\
\left(1.87 E^{-5}\right)\end{array}$ & 12.0 & $\begin{array}{c}0.773 \\
(12)\end{array}$ \\
\hline $\begin{array}{l}\mathrm{CO}_{2} \\
(\mathrm{SD})\end{array}$ & $\begin{array}{c}5.25 \\
(0.404)\end{array}$ & $\begin{array}{l}0.059 \\
(1.31)\end{array}$ & 25.7 & $\begin{array}{c}2.04 \mathrm{E}^{-1} \\
\left(1.39 \mathrm{E}^{-1}\right)\end{array}$ & $\begin{array}{c}2.15 E^{-3} \\
\left(5.23 E^{-4}\right)\end{array}$ & 1.2 & $\begin{array}{c}0.838 \\
(23)\end{array}$ \\
\hline
\end{tabular}



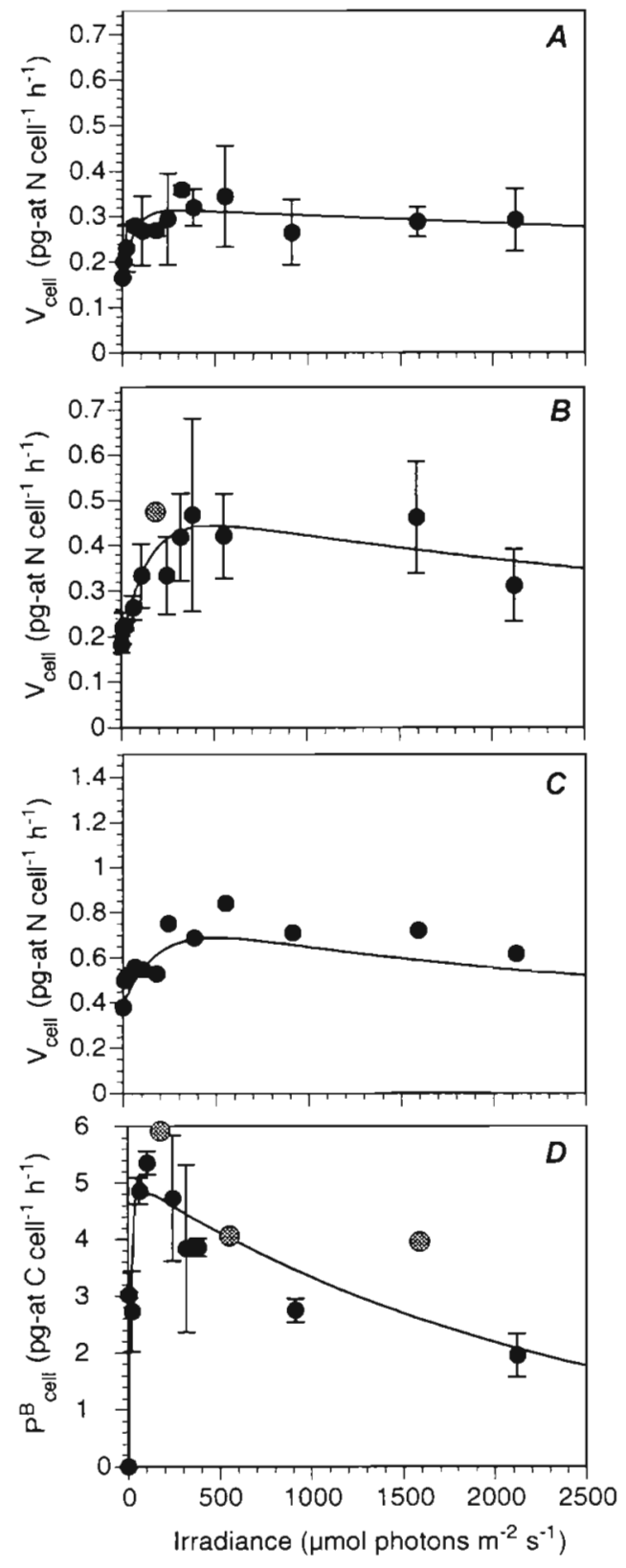

Fig. 3. Nitrogen (A: $\mathrm{NO}_{3}{ }^{-} ; \mathrm{B}: \mathrm{NH}_{4}{ }^{+} ; \mathrm{C}$ : urea) and (D) carbon uptake as a function of irradiance for a natural assemblage of Lingulodinium polyedrum off Newport Beach, California. The curved plots are fitted directly to the 3 -parameter $P$ versus $E$ curve (Platt \& Gallegos, 1980) modified to account for dark uptake (Cochlan et al. 1991). Error bars indicate \pm 1 SD of replicate samples, except for urea (C) for which there were no replicates. data were not included in the curve fit or in the estimation of kinetic parameters. non-replicate data

1981, Meeson \& Sweeney 1982, Prézelin \& Matlick 1983) physiological responses in this species. To date, however, no study has examined the nitrogen kinetics and photosynthetic response of this species simultaneously. Our reported values also represent one of the few descriptions of the dynamics of urea uptake for a dinoflagellate under natural bloom conditions.

Previous field observations coupled with studies in the laboratory have led to the speculation that Lingulodinium polyedrum achieves maximal biomass concentrations in nutrient-depleted waters by vertically migrating through the nutricline at night (Maclsaac 1978, Heaney \& Eppley 1981). By doing so, L. polyedrum could maximize its ability to utilize $\mathrm{NO}_{3}{ }^{-}$in the dark, which could account for 50 to $100 \%$ of its nitrogenous nutrition (Harrison 1976), while photosynthesizing during the daylight hours. Our results confirm that L. polyedrum is capable of maintaining significant uptake in the dark. It is important to note, however, that the culture room lighting ( $25 \mu \mathrm{mol}$ photons $\mathrm{m}^{-2} \mathrm{~s}^{-1}$ ) was equal to the $E_{\mathrm{k}}$ value for carbon uptake by this species $\left(25.7 \mu \mathrm{mol}\right.$ photons $\mathrm{m}^{-2} \mathrm{~s}^{-1}$ ), suggesting that significant amounts of stored photosynthate may have been present before the initiation of the experiment. Although elevated dark-uptake values are often associated with $\mathrm{N}$ deficiency (e.g. Harrison 1976, Paasche et al. 1984), this interpretation is confounded by the often high rates of dark-N uptake found in $L$. polyedrum, even under $\mathrm{N}$-sufficient conditions (Eppley \& Harrison 1975, Harrison 1976, MacIsaac 1978, Heaney \& Eppley 1981). Harrison (1976) showed that in culture, dark $\mathrm{NO}_{3}{ }^{-}$uptake was enhanced from ca 20 to $40 \%$ of the light assimilation value when the culture was nitrogen starved, and that dark-uptake was more affected by starvation than was light uptake. Heaney \& Eppley (1981) also showed that L. polyedrum exhibits complex behavior when nutrient limited, including avoidance of high light levels and cessation of vertical migration. In their data, this was accompanied by a rapid (ca $1 \mathrm{~d}$ ) drop in the atomic $\mathrm{C}: \mathrm{N}$ ratio from 8.5 to 6.5 with the addition of nitrogen. For our experiments, dark uptake accounted for ca $45 \%$ of total $N$ uptake and the mean $\mathrm{C}: \mathrm{N}$ ratio from the ${ }^{13} \mathrm{C}$ samples was $9.1 \pm$ $0.20( \pm \mathrm{SE}$ ). Based on the references cited above, this suggests that the assemblage was approaching nitrogen limitation. This remains speculative, however, given the wide range of dark-uptake capacities and $\mathrm{C}: \mathrm{N}$ ratios in this and other algal species.

Heterotrophic uptake (especially by bacteria) of dissolved $\mathrm{N}$ compounds could also contribute to our measured dark-uptake rates. However, the elevated concentrations of Lingulodinium polyedrum would make the contribution of other potential competitors negligible in the measured uptake rates. Bacteria are known to preferentially utilize ammonium before nitrate or urea (e.g. Kirchman 1994, Kirchman et al. 1994, Kirchman \& Wheeler 1998), and may gain most of their nitrogen requirement from dissolved free amino acids in coastal environments (Billen \& Fontigny 1987, Kirchman 1994, but see Kirchman \& Wheeler 1998). Auto- 
trophic organisms have also been shown to outcompete heterotrophs at elevated substrate concentrations (Suttle et al. 1990) such as were measured at our study site. We are therefore confident that our dark uptake rates are not representative of heterotrophic uptake given the elevated ambient concentrations of ammonium and the use of near-saturating additions of $\mathrm{N}$ in our uptake versus irradiance experiments.

Based on $V_{\max }$ values, apparent $\mathrm{N}$ utilization followed the order: urea, $\mathrm{NH}_{4}{ }^{+}, \mathrm{NO}_{3}{ }^{-}$. Calculation of the $f$-ratio $\left[f=V_{\mathrm{NO}_{3}} /\left(V_{\mathrm{NO}_{3}}+V_{\mathrm{NH}_{4}}+V_{\text {urea }}\right)\right]$ at ambient nutrient concentrations also demonstrates a reliance on regenerated forms of nitrogen, with an estimated value of 0.01 . This value was calculated using the MichaelisMenten equation and the kinetics parameters from Table 1. Even if saturating concentrations of $\mathrm{NO}_{3}{ }^{-}$were present (for example if the population were to vertically migrate below the nutricline), simple calculations demonstrate that the $f$-ratio would only rise to 0.29 . This value is based on the measured uptake rates and kinetics parameters (Table 1) when the ambient $\mathrm{NH}_{4}{ }^{+}$and urea concentrations are held constant and the $\mathrm{NO}_{3}{ }^{-}$concentration is increased to $12 \mu \mathrm{g}$-at $\mathrm{N} \mathrm{l}^{-1}$, stoichiometrically equal to the ambient $\mathrm{Si}(\mathrm{OH})_{4}{ }^{4-}$ concentration. Calculation of the percent urea uptake $\left(\%\right.$ Uptake $_{\text {urea }}=\left[V_{\text {urea }} /\left(V_{\text {urea }}+V_{\mathrm{NH}_{4}}+V_{\mathrm{NO}_{3}}\right) \times 100\right]$, determined using kinetics parameters from Table 1 and average nutrient concentrations (in the upper $10 \mathrm{~m}$ ), provides a relative urea utilization of $33.8 \%$. This value falls well within previously reported literature values for other natural assemblages in oceanic, coastal, polar, upwelling, and freshwater systems (Table 3).

It is possible that the $\mathrm{NO}_{3}{ }^{-}$uptake rates, but apparently not the urea uptake rates, were inhibited by the relatively high ambient $\mathrm{NH}_{4}{ }^{+}$concentrations (e.g. McCarthy 1981) or were diurnally fluctuating. However, Harrison (1976) reported that Lingulodinium polyedrum exhibited no $\mathrm{NH}_{4}{ }^{+}$inhibition at $50 \mu \mathrm{g}$-at $\mathrm{NH}_{4}{ }^{+} \mathrm{I}^{-1}$ for short periods. He also reported maximal $\mathrm{NO}_{3}^{-}$uptake and nitrate reductase (NR) activity at midday in both $\mathrm{N}$-saturated and $\mathrm{N}$-deficient cultures. Similarly, Packard \& Blasco (1974) reported high NR activity in low- $\mathrm{NO}_{3}{ }^{-}$waters. Regardless, the instantaneous nitrogen demand for this assemblage could easily be met by a combination of $\mathrm{NH}_{4}{ }^{+}$and urea assimilation (assuming 7:1 $\mathrm{C}: \mathrm{N}$ assimilation ratio, a sustained $V_{\max }$ for $\mathrm{C}$ uptake, and saturating irradiances). It is important to note, however, that sustained uptake at $V_{\max }$ could deplete the ambient nutrient pools in about $4 \mathrm{~h}$, requiring an equally rapid regeneration rate to maintain this growth rate.

MacIsaac (1978) in a study of a naturally occurring bloom off the Baja peninsula argued that Lingulodinium polyedrum required both sufficient land simul- taneous) surface light and $\mathrm{NO}_{3}{ }^{-}$to achieve red tide concentrations, and that there was no evidence for the vertical migration and dark uptake of $\mathrm{NO}_{3}{ }^{-}$. Although our $E_{\mathrm{k}}$ values ( 3 to $12 \%$ of near-surface light) are similar to the values Maclsaac (1978) reported (ca 4 and $10 \%$ for $\mathrm{NO}_{3}{ }^{-}$and $\mathrm{NH}_{4}{ }^{+}$respectively), MacIsaac also reported insignificant dark-uptake of $\mathrm{NO}_{3}{ }^{-}$. Prézelin \& Matlick (1983) demonstrated that under nutrient-limiting conditions, L. polyedrum is more susceptible to photo-damage, while Heaney \& Eppley (1981) reported that under nutrient-limiting conditions, L. polyedrum will delay or even cease vertical migration into higher light. These behavioral adaptations likely provide both prolonged exposure to higher subsurface $\mathrm{NO}_{3}{ }^{-}$levels, and avoid photodamage associated with the near surface.

In this study, uptake rates for all of the tested substrates demonstrated at least some photoinhibition ( $\beta$ values; Table 2 ). The carbon data were more pronounced in this inhibition, which is not unexpected given the extremely low $E_{\mathrm{k}}$ value and the direct dependence on light for carbon assimilation. Nitrogen uptake is potentially buffered by the ability to utilize indirect sources of reducing energy, and so would not be expected to demonstrate the same degree of dependency on irradiance. Notably, however, uptake rates at even the highest irradiance $\left(>2100 \mu \mathrm{mol}\right.$ photons $\mathrm{m}^{-2}$ $\mathrm{s}^{-1}$ ) were not appreciably depressed, with $\mathrm{N}$ uptake rates at 63 to $90 \%$ of $V_{\max }$. Given the elevated dark-uptake of $N$, this lack of suppression may be partly explained by the lack of dependence on photon fluences for $N$ uptake. However, examination of the dark-corrected $V_{\max }$ values ( $V_{\text {max }}^{\prime}$ icalculated as $V_{\text {max }}^{\prime}=V_{\max }-$ $V_{\text {dark }}$ ) indicates that $N$ uptake for the highest light levels remained at $>50 \%$ of $V_{\max }^{\prime}$ while the light-inhibited carbon uptake rates were ca $37 \%$ of $V_{\max }$.

Despite the low $E_{\mathrm{k}}$ values, this assemblage was capable of maintaining uptake rates of all $\mathrm{N}$ substrates at $50 \%$ of $V_{\max }$ or better, even at the highest irradiance $\left(2119 \mu \mathrm{mol}\right.$ photons $\left.\mathrm{m}^{-2} \mathrm{~s}^{-1}\right)$. This irradiance is unlikely to be encountered for any length of time in ecologically relevant conditions, given that it was achieved at noon in a Plexiglas ${ }^{\oplus}$ incubator. These data, together with the dark-uptake values which demonstrated that Lingulodinium polyedrum could maintain 37 to $52 \%$ of $V_{\max }$ in darkness, indicate that this dinoflagellate is capable of maintaining high uptake rates of nitrogenous substrates at all light levels. Similarly, photosynthetic carbon assimilation reached $50 \%$ of $V_{\max }$ at the extremely low level of $1.2 \%$ of surface irradiance, and was still at $37 \%$ of $V_{\max }$ at the highest light levels (Fig. 3D). It is possible to calculate the apparent demand for nitrogen at varying light levels and ambient nutrient concentrations based on our reported uptake versus irradiance and uptake versus substrate concentration kinetic 


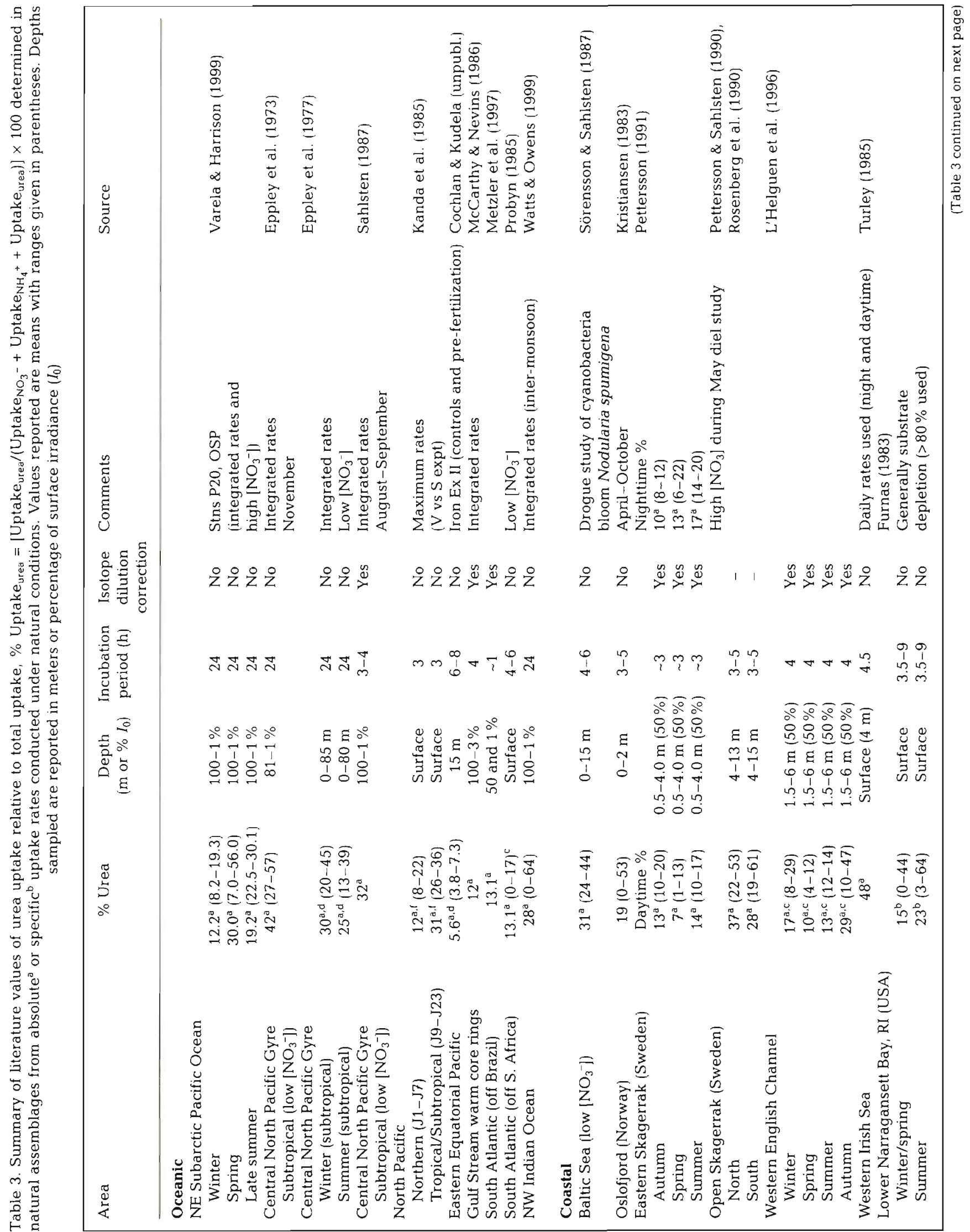




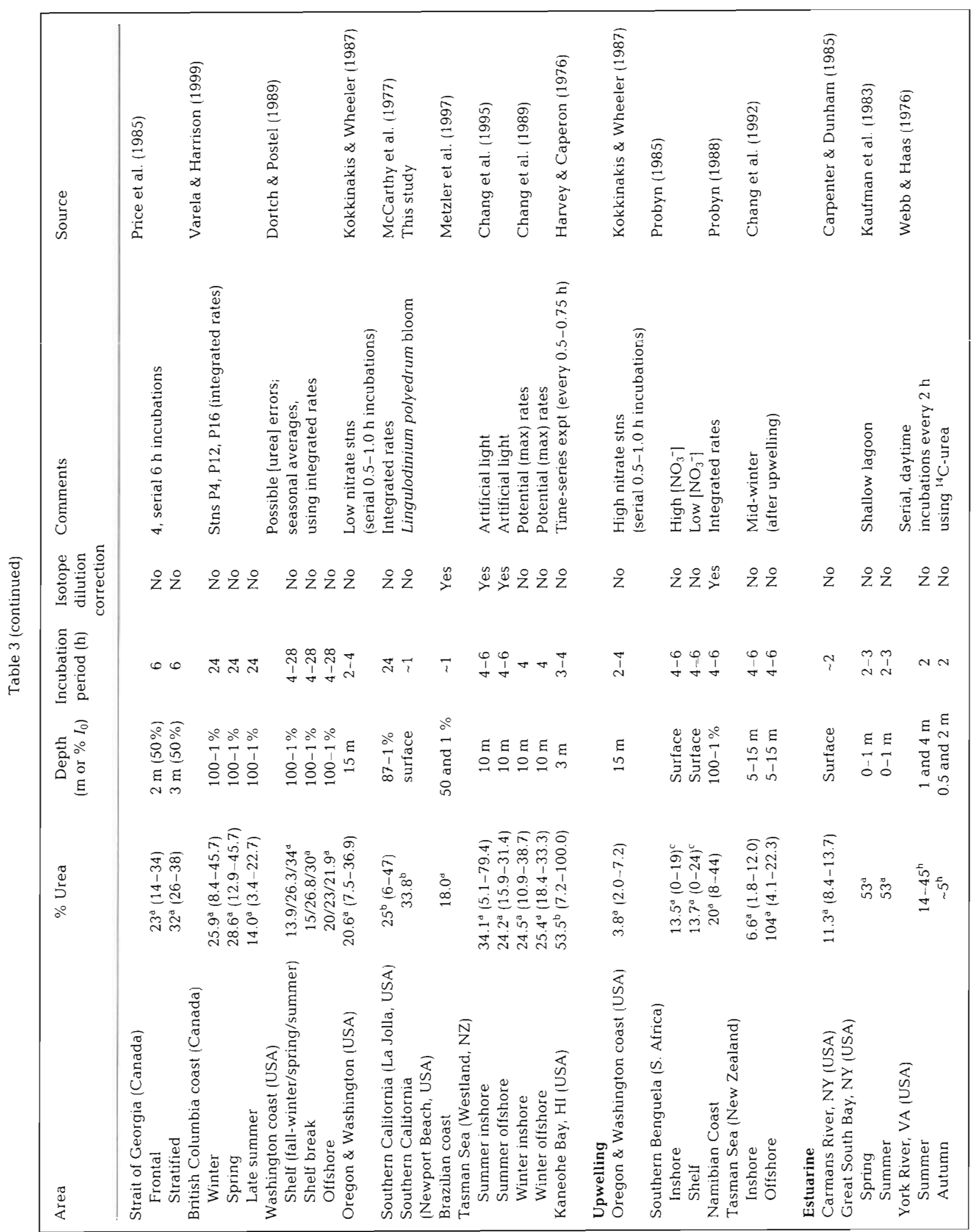



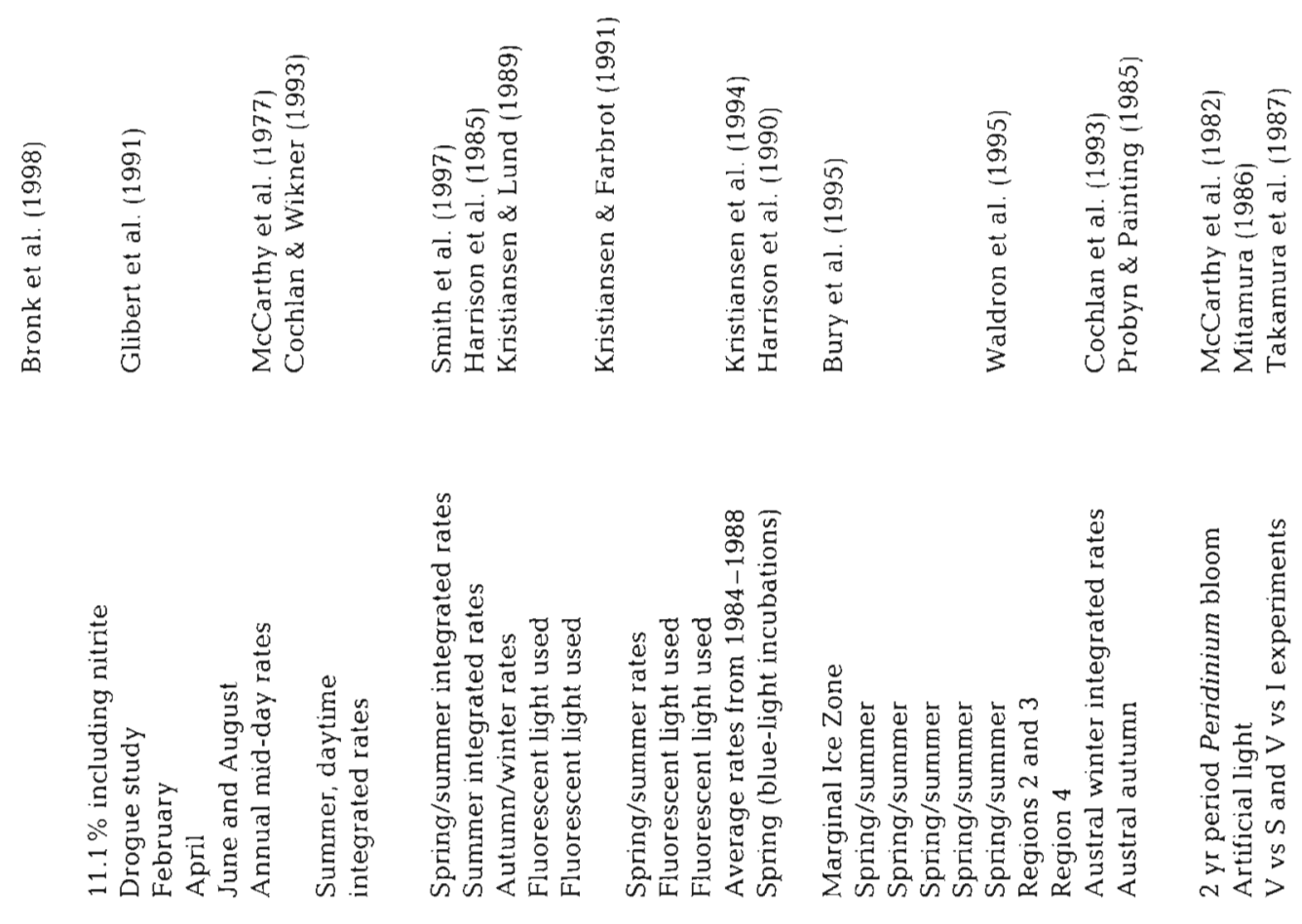

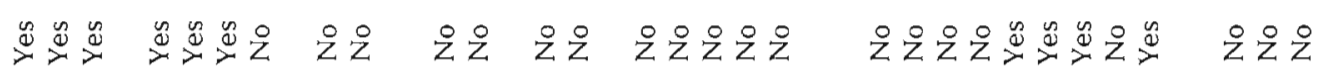

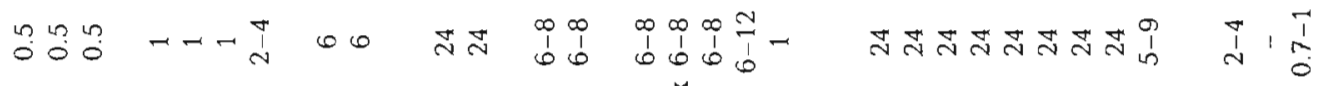

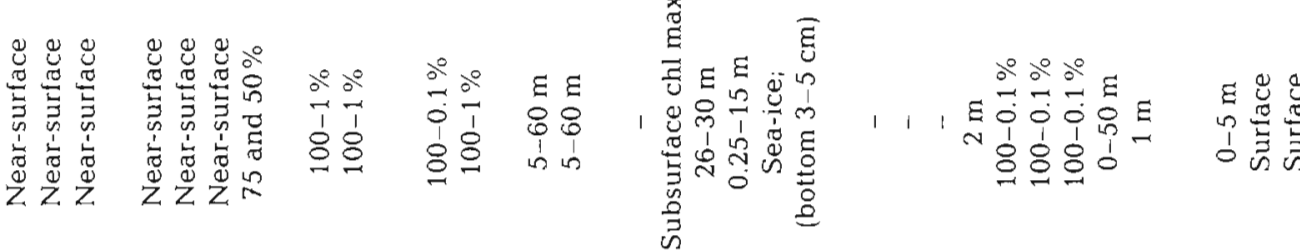

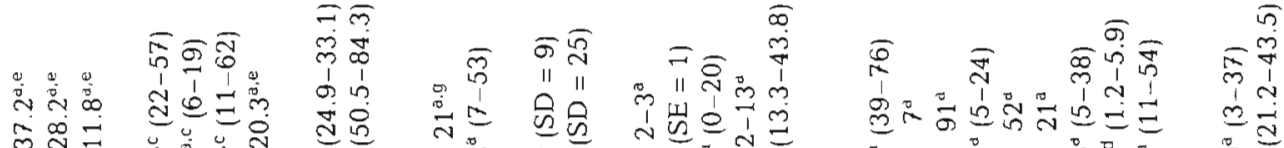

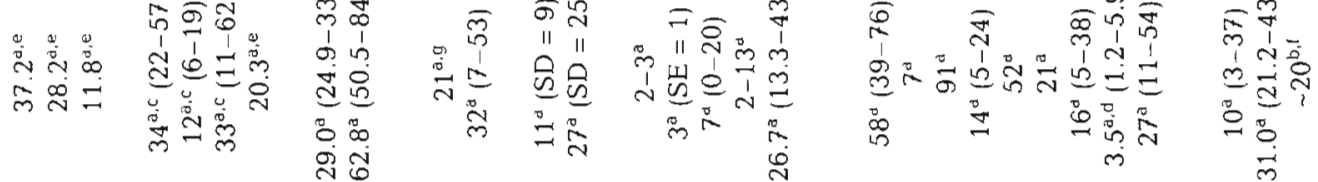

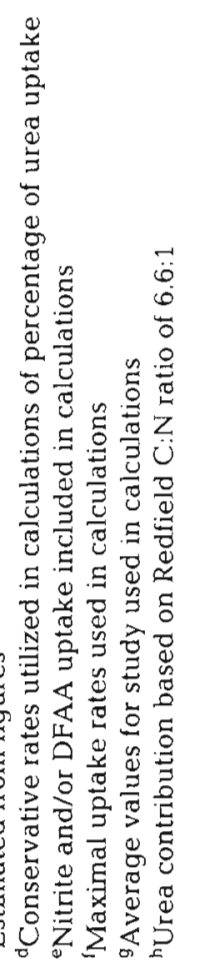


parameters, and the reported atomic C:N ratio of 9:1 (Fig. 4). Fig. 4A provides the potential uptake of nitrogen at ambient concentrations of substrate (using the average concentration in the upper $10 \mathrm{~m}$ of the water column) versus irradiance. To determine these rates, we used Eq. (1) to calculate an ambient $V$ value based on the kinetics parameters reported in Table 1 and the average nutrient concentration. We then used the calculated ambient $V$ in Eq. (2) as $V_{\mathrm{s}}$ to determine ambient uptake versus irradiance (Fig. 4A). In Fig. 4B, the same data are presented as $\mathrm{C}: \mathrm{N}$ assimilation ratios individually and for varying combinations of nutrient uptake, again as a function of irradiance.

Interpretation of these plots is somewhat difficult since the measurements were conducted at a single time point and we are assuming that the nutrient kinetics and uptake versus irradiance responses are both independent and representative of the population as a whole. However, several important points can be
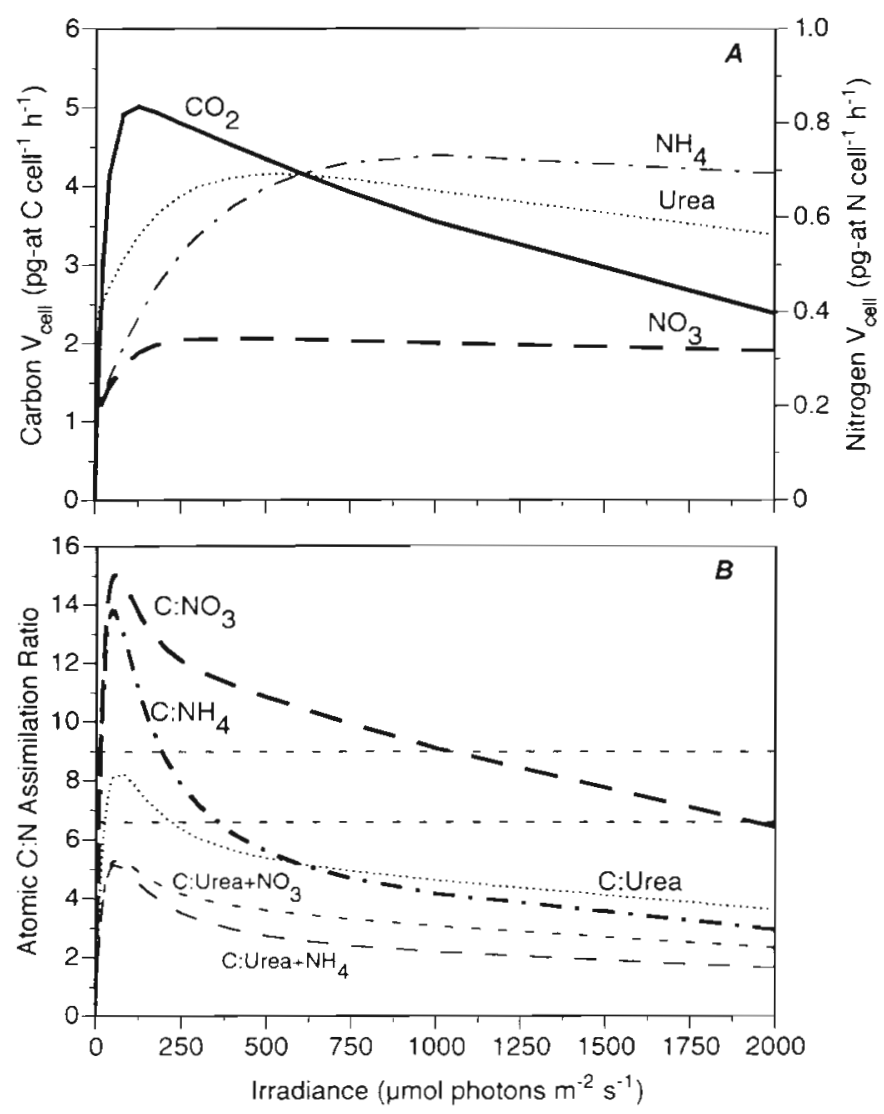

Fig. 4. (A) Uptake versus irradiance plots for all substrates are plotted using the calculated uptake values at ambient nutrient concentrations as described in the text. Note that $N$ uptake parameters are on a separate $y$-axis. (B) Provides the same data plotted as $\mathrm{C}: \mathrm{N}$ assimilation ratios versus irradiance for differing combinations of nitrogen. The dashed horizontal lines represent the measured atomic $C: N$ ratio for the assemblage (9:1) and the Redfield ratio (6.6:1) made. First, the low ambient concentrations of $\mathrm{NO}_{3}{ }^{-}$ make this substrate the least utilizable form of nitrogen for this assemblage, while the ability to efficiently utilize urea and $\mathrm{NH}_{4}{ }^{+}$at ambient concentrations and all light levels suggests a greater reliance on these reduced forms of nitrogen for growth. Second, if the assemblage were to maintain its atomic $\mathrm{C}: \mathrm{N}$ ratio at 9:1, all of the nitrogen requirement could be met by urea assimilation alone. If the desired $\mathrm{C}: \mathrm{N}$ ratio is closer to Redfield proportions (6.6:1), nitrogen demand could be met by utilizing urea subsidized with either $\mathrm{NH}_{4}{ }^{+}$or $\mathrm{NO}_{3}{ }^{-}$. Third, exclusive reliance on $\mathrm{NO}_{3}{ }^{-}$assimilation could only meet the $\mathrm{N}$ demand at either extremely low or extremely high irradiance levels, while $\mathrm{NH}_{4}{ }^{+}$utilization capacity falls between $\mathrm{NO}_{3}{ }^{-}$and urea. Reliance on urea or $\mathrm{NH}_{4}{ }^{+}$of course requires a continuous supply of these nutrients, since at the cell abundance and nutrient concentrations measured the population could strip the water column of all the $\mathrm{N}$ in less than a day.

We observed an approximate doubling of cell number during the ca $24 \mathrm{~h}$ in which the samples were held in the laboratory, with an approximately 4 -fold decrease in chlorophyll per cell (from 125 to $61 \mathrm{\mu g} \mathrm{l}^{-1}$ cell $^{-1}$; the relative proportion of phaeopigments did not change). Conditions in the culture room $(25 \mu \mathrm{mol}$ photons $\mathrm{m}^{-2} \mathrm{~s}^{-1}$ ) were equivalent to considerably less than $5 \mathrm{~m}$ depth at noon for our collection site, using a zenith solar irradiance of $2300 \mu \mathrm{mol}$ photons $\mathrm{m}^{-2} \mathrm{~s}^{-1}, 15 \%$ loss at the air/water interface (Kirk 1994), and the measured $K_{\mathrm{PAR}}$ value of $1.075 \mathrm{~m}^{-1}$. Before and after the solar zenith, this depth would be proportionately shallower. Possible mechanisms for the decrease in cell pigmentation include photo-adaptation (since mean light levels in the culture room were constant and possibly higher than the average mixed-layer depth) and/or catabolization of the pigments as a nitrogen source to support growth. Final cell chl a levels (ca $35 \mathrm{pg} \mathrm{chl} \mathrm{a} \mathrm{cell-1}$ ) are consistent with the results reported by Prézelin \& Sweeney (1979) for high- and low-light cultures (44 and $77 \mathrm{pg} \mathrm{chl} \mathrm{a} \mathrm{cell}{ }^{-1}$, respectively) and Prézelin \& Matlick (1983) for N-limited (35 to $54 \mathrm{pg} \mathrm{chl} \mathrm{a} \mathrm{cell}{ }^{-1}$ ) and N-saturated (increase to ca $72 \mathrm{pg}$-at $\mathrm{chl}$ a cell-1) cultures. In southern California, reported values for natural assemblages range from 22 to $38 \mathrm{pg} \mathrm{chl} \mathrm{a} \mathrm{cell}{ }^{-1}$ (Holmes et al. 1967), $114 \mathrm{pg} \mathrm{cell}^{-1}$ at our study site, and with the presumed pigment concentrations of $260 \mathrm{pg}$ chl a cell ${ }^{-1}$

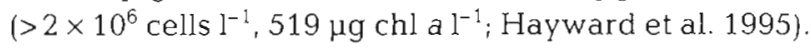
The growth rate suggests that the phytoplankton assemblage was not yet severely nutrient limited (typical growth rates range from 0.4 to 1.0 doublings $d^{-1}$ in natural samples, ca 0.2 doublings $\mathrm{d}^{-1}$ in culture; Walsh et al. 1974, Eppley \& Harrison 1975, Harrison 1976, Prézelin \& Sweeney 1979). Unfortunately we do not have a direct estimate of the regeneration rates during this experiment. The presence of $>50 \%$ of the plank- 
tonic biomass as Noctiluca scintillans, and the extremely high total biomass combined with the potential for the catabolization of the chl a pool and the lack of inorganic nitrogen in the carboys suggest that all of the $\mathrm{N}$ demand in vitro was met by recycled nitrogen and/or a decrease in $\mathrm{N}$ per cell. Whether a similar mechanism occurred in situ is impossible to determine from these data, and we have no evidence for or against the Lingulodinium polyedrum population in this study augmenting their $\mathrm{N}$ nutrition by vertically migrating. However, based on the measured $f$-ratio and the ability of L. polyedrum to meet essentially all of its nitrogen requirements from regenerated sources, we believe that it is not necessary to invoke vertical migration from a nutritional standpoint.

Another trend reported in the literature that we could not corroborate in our study were the high $K_{\mathrm{s}}$ values for $\mathrm{NO}_{3}{ }^{-}$and $\mathrm{NH}_{4}{ }^{+}$(Table 4 ), which are about 1 order of magnitude higher than the values reported here (Table 1). Harrison (1976) reported a $K_{\mathrm{s}}$ value for $\mathrm{NO}_{3}^{-}$uptake in cultures that was similar to ours (ca $1 \mu \mathrm{g}$-at $\mathrm{N}$ ), but went on to conclude that this 'low value' was likely due to poor growth rates in culture $\left(0.2 \mathrm{~d}^{-1}\right)$. Because $K_{\mathrm{s}}$ values themselves are often misleading, we have also presented $\alpha_{N}$ values. Comparisons of our measured $\alpha_{N}$ values are similar to the historical estimates for $\mathrm{NO}_{3}{ }^{-}$, but are at the upper range of previously reported values. Since our $\alpha_{N}$ value for $\mathrm{NO}_{3}{ }^{-}$is the lowest of the 3 substrates tested, we again conclude that natural assemblages of Lingulodinium polyedrum can exhibit higher than expected from literature values) affinities for reduced nitrogen. It is apparent that under stratified conditions where dia-

Table 4. Kinetic parameters for nitrate uptake of Lingulodinium polyedrum from culture and natural assemblages. There were no literature values for ammonium and urea uptake (except $\mathrm{NH}_{4}{ }^{+} K_{\mathrm{s}}=5.5$; Eppley et al. 1969). The $V_{\text {max }}$ value for Dugdale (1979) is in units of $\mathrm{h}^{-1}$, since no cell counts were provided. Units for the other parameters are the same as Table 1. Parameters from Harrison (1976) were estimated from his Fig. 6

\begin{tabular}{|c|c|c|c|}
\hline$V_{\max }$ & $K_{\mathrm{s}}$ & $\alpha_{N}$ & Source \\
\hline- & 9.50 & - & Eppley et al. (1969) \\
\hline 0.14 & 0.50 & 0.280 & Dugdale (1979) \\
\hline 7.82 & 10.5 & 0.745 & Harrison $(1976)^{\mathrm{d}}$ \\
\hline 3.20 & 3.46 & 0.945 & Harrison $(1976)^{a}$ \\
\hline 1.13 & 7.20 & 0.157 & Harrison (1976) \\
\hline 4.38 & 15.1 & 0.290 & Harrison (1976) \\
\hline $0.13-0.50$ & $0.5-2.0$ & $0.250-0.260$ & Harrison $(1976)^{b}$ \\
\hline 2.24 & 2.40 & 0.933 & Balch (1987) \\
\hline 0.480 & 0.467 & 1.03 & This study \\
\hline \multicolumn{4}{|c|}{ 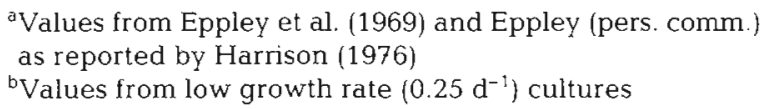 } \\
\hline
\end{tabular}

toms fare poorly (e.g. Margalef 1978), L. polyedrum is extremely competitive for both light and nitrogen.

Our $K_{\mathrm{s}}$ values for $\mathrm{NO}_{3}{ }^{-}, \mathrm{NH}_{4}{ }^{+}$and urea suggest that Lingulodinium polyedrum is capable of competing with typical coastal phytoplankton such as diatoms. Those studies which have simultaneously examined uptake kinetics for urea, $\mathrm{NO}_{3}^{-}$and $\mathrm{NH}_{4}{ }^{+}$(Table 5) demonstrate that urea utilization is consistently in the same range as for $\mathrm{NO}_{3}{ }^{-}$and $\mathrm{NH}_{4}{ }^{+}$in natural assemblages. Our study is no exception, and it is clear that there is no a priori reason for believing that $L$. polyedrum cannot compete (from a physiological perspective) with other coastal assemblages. The reported values are more in range with previously reported values for neritic diatoms and flagellates, with $K_{\mathrm{s}}(\mathrm{SD})=1.66$ $( \pm 0.07)$ and $1.82( \pm 0.09) \mu \mathrm{g}$-at $\mathrm{N} \mathrm{l}^{-1}$ for $\mathrm{NO}_{3}{ }^{-}$and $\mathrm{NH}_{4}{ }^{+}$ respectively (Eppley et al. 1969). Our estimated halfsaturation constants for urea are the first reported for $L$. polyedrum and are similar to the few values reported for cultures of marine neritic diatoms $(0.4$ to $2.0 \mu \mathrm{g}$-at $\mathrm{N} \mathrm{l}^{-1}$; McCarthy 1972, Rees \& Syrett 1979), freshwater chlorophytes (generally 0.2 to $1.8 \mu \mathrm{g}$-at $\mathrm{N} \mathrm{I}^{-1}$; Healey 1977, Kirk \& Kirk 1978), the freshwater cyanobacterium Pseudoanabaena catenata $\left(0.8 \mu \mathrm{g}\right.$-at $\mathrm{N} \mathrm{I}^{-1}$; Healey 1977), the picoflagellate Micromonas pusilla $\left(0.4 \mu \mathrm{g}\right.$-at $\mathrm{N}^{-1}$; Cochlan \& Harrison 1991), and the neritic marine bacterium Deleya venusta $\left(2.8 \mu \mathrm{g}\right.$-at $\mathrm{N}^{-1}$;

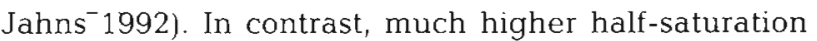
constants have also been reported for cultures of the inshore diatom Skeletonema costatum (8.5 $\mu \mathrm{g}$-at $\mathrm{N} \mathrm{I}^{-1}$; Carpenter et al. 1972), some freshwater chlorophytes (5 to $30 \mu \mathrm{g}$-at $\mathrm{N}^{-1}$; Syrett \& Bekheet 1977 , Williams \& Hodson 1977, Kirk \& Kirk 1978, Bekheet \& Syrett 1979) and the lacustrine diatom Melosira italica $(0.13$ to $22 \mu \mathrm{g}$-at $\mathrm{N}^{-1}$; Cimbleris \& Cáceres 1991).

Hayward et al. (1995) reported that the Lingulodinium polyedrum population was present in southern California coastal waters prior to the beginning of the heavy rainfall and associated runoff beginning in January 1995. They speculated that the peak biomass associated with our sampling period in March was likely triggered by the heavy rains just prior to this time, which, combined with the intense solar heating, caused strong stratification and isolation of the anthropogenic nutrients in the surface waters. Urea is a likely contaminant in heavily urbanized regions such as our study site (e.g. Antia et al. 1991) and was found at elevated ambient concentrations despite the demonstrated capacity for uptake by the dominant autotrophic species, L, polyedrum.

This opportunistic study clearly cannot evaluate the physiological condition and nutritional status of this bloom during either the formational period or the subsequent crash. Therefore, our results are more representative of a physiological 'snapshot' during a red 


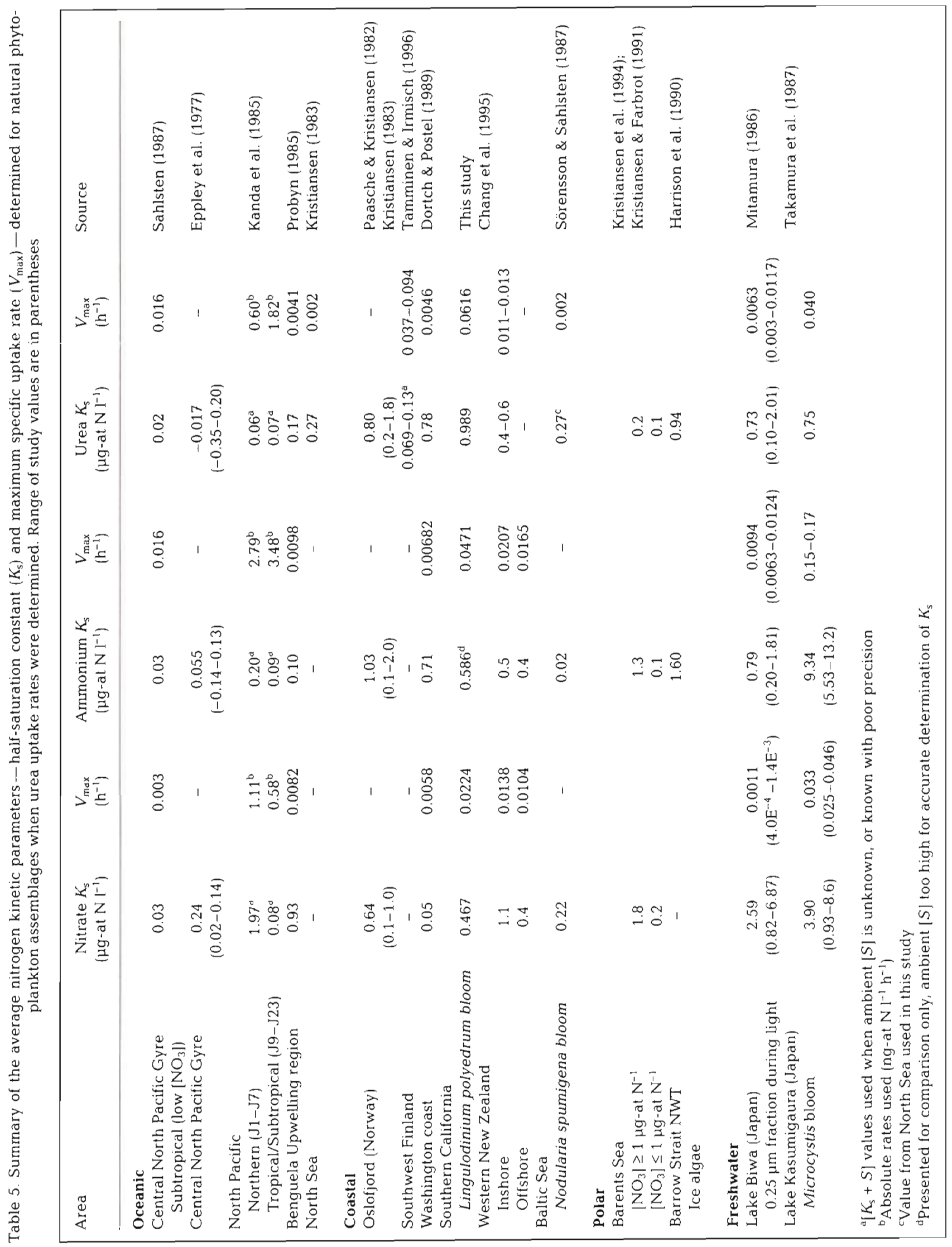


tide event. However, we are confident that these data clearly demonstrate that Lingulodinium polyedrum exhibits $K_{\mathrm{s}}$ values typical of other coastal species, and that this species is capable of utilizing a broad range of both nitrogen concentrations and light fluences. It is not necessary to invoke vertical migration accompanied by dark- $\mathrm{N}$ uptake to meet the nutritional demands of this assemblage. This study also demonstrates that $L$. polyedrum can readily utilize urea as a nitrogen source. Although this is not surprising, it nevertheless remains one of the few studies demonstrating that dinoflagellates and other red tide organisms make use of this potentially anthropogenic source of nitrogen for growth.

Acknowledgements. We thank Mr R. Profita and the students of Orange Coast College 'Marine Biology 180L class' for their assistance at sea. Use of the analytical facilities of Dr R. C. Dugdale is gratefully acknowledged. The comments and suggestions of 3 anonymous reviewers greatly improved our original manuscript and provided the basis for the presentation of Fig. 4. This study was supported by a National Aeronautic and Space Administration Global Change Fellowship (to R.M.K.) and the University of Southern California Sea Grant Program (grant no. NA 90 AA-D-SG-525), NOAA Dept. of Commerce and the California State Resources Agency (to W.P.C.).

\section{LITERATURE CITED}

Antia NJ, Harrison PJ, Oliveira L (1991) The role of dissolved organic nitrogen in phytoplankton nutrition, cell biology and ecology. Phycologia 30:1-89

Armstrong FAJ, Stearns CR, Strickland JDH (1967) The measurement of upwelling and subsequent biological processes by means of the Technicon Autoanalyzer and associated equipment. Deep-Sea Res 14:381-389

Balch WM (1985) Differences between dinoflagellates and diatoms in the uptake of ${ }^{36} \mathrm{Cl}-\mathrm{ClO}_{3}$, an analogue of $\mathrm{NO}_{3}$. In: Anderson D, White A, Baden D (eds) Toxic dinoflagellates. Elsevier, New York, p 121-124

Balch WM (1987) Studies of nitrate transport by marine phytoplankton using ${ }^{36} \mathrm{Cl}-\mathrm{ClO}_{3}^{-}$as a transport analogue. I. Physiological findings. J Phycol 23:107-118

Bekheet IA, Syrett PJ (1979) The uptake of urea by Chlorella. New Phytol 82:179-186

Billen G, Fontigny A (1987) Dynamics of a Phaeosystis-dominated spring bloom in Belgian coastal waters. II. Bacterioplankton dynamics. Mar Ecol Prog Ser 37:249-257

Bronk DA, Glibert PM, Malone TC, Banahan S, Sahlsten E (1998) Inorganic and organic nitrogen cycling in Chesapeake Bay: autotrophic versus heterotrophic processes and relationships to carbon flux. Aquat Microb Ecol 15: $177-189$

Bury SJ, Owens NJP, Preston T (1995) ${ }^{13} \mathrm{C}$ and ${ }^{15} \mathrm{~N}$ uptake by phytoplankton in the marginal ice zone of the Bellingshausen Sea. Deep-Sea Res II 42:1225-1252

Buskey EJ (1995) Growth and bioluminescence of Noctiluca scintillans on varying algal diets. J Plankton Res 17:29-40

Carpenter EJ, Dunham S (1985) Nitrogenous nutrient uptake, primary production, and species composition of phytoplankton in the Carmans River estuary, Long Island, New
York. Limnol Oceanogr 30:513-526

Carpenter EJ, Remsen CC, Watson SW (1972) Utilization of urea by some marine phytoplankters. Limnol Oceanogr $17: 265-269$

Chang FH, Vincent WF, Woods PH (1989) Nitrogen assimilation by three size fractions of the winter phytoplankton off Westland, New Zealand. NZ J Mar Freshw Res 23: 491-505

Chang FH, Vincent WF, Woods PH (1992) Nitrogen utilization by size-fractionated phytoplankton assemblages associated with an upwelling event off Westland, New Zealand. NZ J Mar Freshw Res 26:287-301

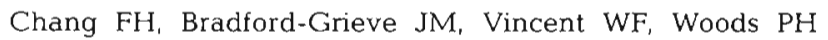
(1995) Nitrogen uptake by summer size-fractionated phytoplankton assemblages in the Westland, New Zealand, upwelling system. NZ J Mar Freshw Res 29:147-161

Cimbleris ACP, Cáceres O (1991) Kinetics of urea uptake by Melosira italica (Ehr.) Kutz at different luminosity conditions. Hydrobiologica 220:211-216

Cochlan WP, Harrison PJ (1991) Kinetics of nitrogen (nitrate, ammonium and urea) uptake by the picoflagellate Micromonas pusilla (Prasinophyceae). J Exp Mar Biol Ecol 153: 129-141

Cochlan WP, Wikner J (1993) Nitrogen uptake by size-fractionated microorganisms in the Gulf of Bothnia, Sweden. The Oceanographic Society Meeting, Seattle, WA (Abstract)

Cochlan WP, Harrison PJ, Denman KL (1991a) Diel periodicity of nitrogen uptake by marine-phytoplankton in nitraterich environments. Limnol Oceanogr 36:1689-1700

Cochlan WP, Price NM, Harrison PJ (1991b) Effects of irradiance on nitrogen uptake by phytoplankton: comparison of frontal and stratified communities. Mar Ecol Prog Ser 69: $103-116$

Cochlan WP, Martinez J, Holm-Hansen O (1993) RACER: utilization of nitrate, ammonium, and urea during austral winter in Gerlache Strait, Antarctica. Antarct J US 28: 169-172

Dortch Q, Postel JR (1989) Phytoplankton-nitrogen interactions. In: Landry MR, Hickey BM (eds) Coastal oceanography of Washington and Oregon. Elsevier Science Publishers, Amsterdam, p 139-173

Dowd JE, Riggs DS (1965) A comparison of estimates of Michaelis-Menten kinetic constants from various linear transformations. J Biol Chem 240:863-869

Dugdale RC (1979) Primary nutrients and red tides in upwelling regions. In: Taylor DL, Seliger $\mathrm{HH}$ (eds) Toxic dinoflagellate blooms. Elsevier North Holland, New York, p 257-262

Dugdale RC, Wilkerson FP (1986) The use of ${ }^{15} \mathrm{~N}$ to measure nitrogen uptake in eutrophic oceans; experimental considerations. Limnol Oceanogr 31:673-689

Eppley RW, Harrison WG (1975) Physiological ecology of Gonyaulax polyedra, a red water dinoflagellate off Southern California. In: LoCicero V (ed) First conference of toxic dinoflagellate blooms. Massachusetts Science and Technology Foundation, Wakefield, MA, p 11-22

Eppley RW, Rogers JN, McCarthy JJ (1969) Half-saturation constants for uptake of nitrate and ammonia by marine phytoplankton. Limnol Oceanogr 14:912-920

Eppley RW, Renger EH, Venrick EL, Mullin MM (1973) A study of plankton dynamics and nutrient cycling in the central gyre of the North Pacific Ocean. Limnol Oceanogr 18:534-551

Eppley RW, Sharp JH, Renger EH, Perry MJ, Harrison WG (1977) Nitrogen assimilation by phytoplankton and other microorganisms in the surface waters of the central north Pacific Ocean. Mar Biol 39:111-120 
Frenette JJ, Demers S, Legendre L, Dodson J (1993) Lack of agreement among models for estimating the photosynthetic parameters. Limnol Oceanogr 38:679-686

Furnas MJ (1983) Nitrogen dynamics in lower Narragansett Bay, Rhode Island. I. Uptake by size-fractionated phytoplankton populations. J Plankton Res 5:657-676

Glibert PM, Garside C (1992) Diel variability in nitrogenous nutrient-uptake by phytoplankton in the Chesapeake Bay plume. J Plankton Res 14:271-288

Glibert PM, Lipschultz F, McCarthy JJ, Altabet MA (1982) Isotope dilution models of uptake and remineralization of ammonium by marine plankton. Limnol Oceanogr 27 : $639-650$

Glibert PM, Garside C, Fuhrman JA, Roman MR (1991) Timedependent coupling of inorganic and organic nitrogen uptake and regeneration in the plume of the Chesapeake Bay estuary and its regulation by large heterotrophs. Limnol Oceanogr 36:895-909

Harrison PJ, Parsiow JS, Conway hil (1989) Determination of nutrient uptake kinetic parameters: a comparison of methods. Mar Ecol Prog Ser 52:301-312

Harrison WG (1976) Nitrate metabolism of the red tide dinoflagellate Gonyaulax polyedra Stein. J Exp Mar Biol Ecol 21:199-209

Harrison WG, Head EJH, Conover RJ, Longhurst AR, Sameoto DD (1985) The distribution and metabolism of urea in the eastern Canadian Arctic. Deep-Sea Res 32:23-42

Harrison WG, Cota GF, Smith REH (1990) Nitrogen utilization. in ice algal communities of Barrow Strait, Northwest Territories, Canada. Mar Ecol Prog Ser 67:275-283

Harvey WA, Caperon J (1976) The rate of utilization of urea, ammonium, and nitrate by natural populations of marine phytoplankton in a eutrophic environment. Pac Sci 30: $329-340$

Hayward TL, Cayan DR, Franks PJS, Lynn RJ, Mantyla AW, McGowan JA, Smith PE, Schwing FB, Venrick EL (1995) The state of the California Current 1994-1995: a period of transition. Calif Coop Oceanic Fish Invest Rep 36:19-39

Healey FP (1977) Ammonium and urea uptake by some freshwater algae. Can J Bot 55:61-69

Healey FP (1980) Slope of the Monod equation as an indicator of advantage in nutrient competion. Microbiol Ecol 5:281-286

Heaney SJ, Eppley RW (1981) Light, temperature and nitrogen as interacting factors affecting diel vertical migrations of dinoflagellates in culture. J Plankton Res 3:331-344

Holmes RW, Williams PM, Eppley RW (1967) Red water in La Jolla Bay, 1964-1966. Limnol Oceanogr 12:503-512

Jahns T (1992) Urea uptake by the marine bacterium Deleya venusta HG1. J Gen Microbiol 138:1815-1820

Kanda J, Saino T, Hattori A (1985) Nitrogen uptake by natural populations of phytoplankton and primary production in the Pacific Ocean: regional variability of uptake capacity. Limnol Oceanogr 30:987-999

Kaufman ZG, Lively JS, Carpenter EJ (1983) Uptake of nitrogenous nutrients by phytoplankton in a barrier island estuary: Great South Bay, New York. Estuar Coast Shelf Sci 17:483-493

Kirchman DL (1994) The uptake of inorganic nutrients by heterotrophic bacteria. Microbiol Ecol 28:255-271

Kirchman DL, Wheeler PA (1998) Uptake of ammonium and nitrate by heterotrophic bacteria and phytoplankton in the sub-Arctic Pacific. Deep-Sea Res 45:347-365

Kirchman DL, Ducklow HW, McCarthy JJ, Garside C (1994) Biomass of nitrogen uptake by heterotrophic bacteria during the spring phytoplankton bloom in the North Atlantic Ocean. Deep-Sea Res 41:879-895

Kirk DL, Kirk MM (1978) Amino acid and urea uptake in ten species of Chlorophyta. J Phycol 14:198-203

Kirk JTO (1994) Light and photosynthesis in aquatic ecosystems. Cambridge University Press, Cambridge

Kokkinakis SA, Wheeler PA (1987) Nitrogen uptake and phytoplankton growth in coastal upwelling regions. Limnol Oceanogr 32:1112-1123

Kristiansen S (1983) Urea as a nitrogen source for the phytoplankton in the Oslofjord. Mar Biol 74:17-24

Kristiansen S, Farbrot T (1991) Nitrogen uptake rates in phytoplankton and ice algae in the Barents Sea. Polar Res 10: 187-192

Kristiansen S, Lund BA (1989) Nitrogen cycling in the Barents Sea. I. Uptake of nitrogen in the water column. Deep-Sea Res 36:255-268

Kristiansen S, Farbrot T, Wheeler PA (1994) Nitrogen cycling in the Barents Sea-seasonal dynamics of new and regenerated production in the marginal ice zone. Limnol Oceanogr 39:1630-1642

Lewis $E_{\text {, Wallace }} D$ (1997) Program developed for $\mathrm{CO}_{2}$ system calculations (accessed: May 11, 1999); available at http://cdiac.esd.ornl.gov/oceans/co2rprt.html

Lewis J, Hallett R (1997) Lingulodinium polyedrum (Gonyaulax polyedra) a blooming dinoflagellate. Oceanogr Mar Biol Annu Rev 35:97-161

L'Helguen S, Madec C, Le Corre P (1996) Nitrogen uptake in permanently well-mixed temperate coastal waters. Estuar Coast Shelf Sci 42:803-818

Li WKW, Irwin BD, Dickie PM (1993) Dark fixation of ${ }^{14} \mathrm{C}$ variations related to biomass and productivity of phytoplankton and bacteria. Limnol Oceanogr 38:483-494

MacIsaac JJ (1978) Diel cycles of inorganic nitrogen uptake in a natural phytoplankton population dominated by Gonyaulax polyedra. Limnol Oceanogr 23:1-9

Margalef R (1978) Life-forms of phytoplankton as survival alternatives in an unstable environment. Oceanol Acta 1 493-509

McCarthy JJ (1972) The uptake of urea by natural populations of marine phytoplankton. Limnol Oceanogr 17 $738-748$

McCarthy JJ (1981) The kinetics of nutrient utilization. In Platt T (ed) Physiological basis of phytoplankton ecology Can Bull Fish Aquat Sci 210:211-233

McCarthy JJ, Nevins JL (1986) Utilization of nitrogen and phosphorus by primary producers in warm-core ring $82-B$ following deep convective mixing. Deep-Sea Res 33 $1773-1788$

McCarthy JJ, Taylor WR, Taft JL (1977) Nitrogenous nutrition of the plankton in the Chesapeake Bay. I. Nutrient availability and phytoplankton preferences. Limnol Oceanogr 22:996-1011

McCarthy JJ, Wynne D, Berman T (1982) The uptake of dissolved nitrogenous nutrients by Lake Kinneret (Israel) microplankton. Limnol Oceanogr 27:673-680

Meeson BW. Sweeney BM (1982) Adaptation of Ceratiun furca and Gonyaulax polyedra (Dinophyceae) to different temperatures and irradiances: growth rates and cell volumes. J Phycol 18:241-245

Metzler PM, Glibert PM, Gaeta SA, Ludlam JM (1997) New and regenerated production in the South Atlantic off Brazil. Deep-Sea Res 44:363-384

Mitamura $O(1986)$ Urea metabolism and its significance in the nitrogen cycle in the euphotic layer of Lake Biwa. III. Influence of the environmental parameters on the response of nitrogen assimilation. Arch Hydrobiol 107:281-299

Miyazaki T, Suyama H, Uotani H(1987) Diel changes of uptake of inorganic carbon and nitrogen by phytoplankton, and the relationship between inorganic carbon and nitrogen uptake 
in Lake Nakanuma, Japan. J Plankton Res 9:513-524

Paasche E, Kristiansen S (1982) Nitrogen nutrition of the phytoplankton in Oslofjord, Norway. Estuar Coast Shelf Sci 14: $237-250$

Paasche E, Bryceson I, Tangen K (1984) Interspecific variation in dark nitrogen uptake by dinoflagellates. J Phycol 20: $394-401$

Packard TT, Blasco D (1974) Nitrate reductase activity in upwelling regions. II. Ammonium and light dependence. Tethys 6:269-280

Parsons TR, Maita Y, Lalli C (1984) A manual of chemical and biological methods for seawater analysis. Pergamon Press, New York

Pettersson K (1991) Seasonal uptake of carbon and nitrogen and intracellualr storage of nitrate in planktonic organisms in the Skagerrak. J Exp Mar Biol Ecol 151:121-137

Pettersson K, Sahlsten E (1990) Diel patterns of combined nitrogen uptake and intracellular storage of nitrate by phytoplankton in the open Skagerrak. J Exp Mar Biol Ecol $138: 167-182$

Platt TP, Gallegos CL (1980) Modeling primary production. In: Falkowski PG (ed) Primary productivity in the sea. Plenum Press, New York, p 339-351

Platt T, Jassby D (1976) The relationship between photosynthesis and light for natural assemblages of coastal marine phytoplankton. J Phycol 12:421-430

Press WH, Teukolsky SA, Vetterling WT, Flannery BP (1992) Numerical recipes in C. Cambridge University Press, New York

Prézelin BB, Matlick HA (1983) Nutrient-dependent low-light adaptation in the dinoflagellate Gonyaulax polyedra. Mar Biol 74:141-150

Prézelin BB, Sweeney BM (1979) Photoadaptation of photosynthesis in two bloom-forming dinoflagellates. In: Taylor $\mathrm{DL}$, Seliger $\mathrm{HH}$ (eds) Toxic dinoflagellate blooms. Elsevier North Holland, New York, p 101-106

Price NM, Harrison PJ (1987) A comparison of methods for the measurement of dissolved urea concentrations in seawater. Mar Biol 92:307-319

Price NM, Cochlan WP, Harrison PJ (1985) Time course of uptake of inorganic and organic nitrogen by phytoplankton in the Strait of Georgia: comparison of frontal and stratified communities. Mar Ecol Prog Ser 27:39-53

Probyn TA (1985) Nitrogen uptake by size-fractionated phytoplankton populations in the southern Benguela upwelling system. Mar Ecol Prog Ser 22:249-258

Probyn TA (1988) Nitrogen utilization by phytoplankton in the Namibian upwelling region during austral spring Deep-Sea Res 35:1387-1404

Probyn TA, Painting SJ (1985) Nitrogen uptake by size-fractionated phytoplankton populations in Antarctic surface waters Limnol Oceanogr 30:1327-1332

Rees TAV, Syrett PJ (1979) The uptake of urea by the diatom, Phaeodactylum. New Phytol 82:169-178

Rosenberg R, Dahl E, Edler L, Fyrberg L, Granéli E, Granéli $W$, Hagström $\AA$, Lindahl $O$, Matos MO, Pettersson $K$, Sahlsten E, Tiselius P, Turk V, Wikner J (1990) Pelagic nutrient and energy transfer during spring in the open and coastal Skagerrak. Mar Ecol Prog Ser 61:215-231

Sahlsten E (1987) Nitrogenous nutrition in the euphotic zone of the central North Pacific gyre. Mar Biol 96:433-439

Editorial responsibility: Patricia Glibert,

Cambridge, Maryland, USA
Schradie J, Bliss CA (1962) The cultivation and toxicity of Gonyaulax polyedra. Lloydia 25:214-221

Slawyk G (1979) ${ }^{13} \mathrm{C}$ and ${ }^{15} \mathrm{~N}$ uptake by phytoplankton in the Antarctic upwelling sea: results from the Antipod 1 cruise in the Indian Ocean sector. Aust J Mar Freshw Res 30 $431-448$

Smith W Jr, Gosselin M, Legendre L, Wallace D, Daly K, Kattner G (1997) New production in the Northeast Water Polynya: 1993. J Mar Syst 10:199-209

Sólorzano L (1969) Determination of ammonia in natural waters by the phenolhypochlorite method. Limnol Oceanogr 14:799-801

Sörensson F, Sahlsten E (1987) Nitrogen dynamics of a cyanobacteria bloom in the Baltic Sea: new versus regenerated production. Mar Ecol Prog Ser 37:277-284

Suttle CA, Fuhrman JA, Capone DG (1990) Rapid ammonium cycling and concentration-dependent partititoning of ammonium and phosphate: implications for carbon transfer in planktonic communities. Limnol Oceanogr 35:424-432

Syrett PJ, Bekheet IA (1977) The uptake of thio-urea by Chlorella fusca. New Phytol 79:291-298

Takamura N, Iwakuma T, Yasuno $\mathrm{M}(1987)$ Uptake of ${ }^{13} \mathrm{C}$ and ${ }^{15} \mathrm{~N}$ (ammonium, nitrate and urea) by Microcystis in Lake Kasumigaura. J Plankton Res 9:151-165

Tamminen T, Irmisch A (1996) Urea uptake kinetics of a midsummer planktonic community on the SW coast of Finland. Mar Ecol Prog Ser 130:201-211

Torrey HB (1902) An unusual occurrence of dinoflagellata on the California coast. Am Nat 36:187-192

Turley CM (1985) Biological studies in the vicinity of a shallow-sea tidal mixing front. IV. Seasonal and spatial distribution of urea and its uptake by phytoplankton. Phil Trans $\mathrm{R}$ Soc Lond B 310:471-500

Utermöhl H (1958) Zur Vervollkommung der quantitativen Phytoplankton Methodik. Mitt Int Ver Limnol 9:38

Varela DE, Harrison PJ (1999) Seasonal variability in nitrogenous nutrition of phytoplankton assemblages in the northeast subarctic Pacific Ocean. Deep-Sea Res II 46:2505-2538

Waldron HN, Attwood CG, Probyn TA, Lucas MI (1995) Nitrogen dynamics in the Bellingshausen Sea during the austral spring of 1992. Deep-Sea Res II 42:1253-1276

Walsh JJ, Kelley JC, Whitledge TE, MacIssac JJ (1974) Spinup of the Baja California upwelling ecosystem. Limnol Oceanogr 19:553-572

Watts LJ, Owens NJP (1999) Nitrogen assimilation and the $f$-ratio in the northwestern Indian Ocean during an intermonsoon period. Deep-Sea Res II 46:725-743

Webb KL, Haas LW (1976) The significance of urea for phytoplankton nutrition in the York River, Virginia. In: Wiley $M$ (ed) Estuarine processes, Vol 1 Academic Press, New York, p 90-102

Williams SK, Hodson RC (1977) Transport of urea at low concentrations in Chlamydomonas reinhardi. $\mathrm{J}$ Bacteriol 130: $266-273$

Wood ED, Armstrong FAJ, Richards FA (1967) Determination of nitrate in seawater by cadmium-copper reduction to nitrite. J Mar Biol Assoc UK 47:23-31

Zimmerman RC, SooHoo JB, Kremer JN, D'Argenio DZ (1987) Evaluation of variance approximation techniques for non-linear photosynthesis-irradiance models. Mar Biol 95:209-215

Submitted: August 8, 1998; Accepted: October 20, 1999

Proofs received from author(s): February 3, 2000 